\title{
Sheltered life beneath elytra: three new species of Eutarsopolipus (Acari, Heterostigmatina, Podapolipidae) parasitizing Australian ground beetles
}

\author{
Alihan Katlav ${ }^{1, *}$ (D), Hamidreza Hajiqanbar ${ }^{2, a}$, Markus Riegler ${ }^{1}$ (D), and Owen D Seeman ${ }^{3}$ (D) \\ ${ }^{1}$ Hawkesbury Institute for the Environment, Western Sydney University, Locked Bag 1797, Penrith, NSW 2751, Australia \\ ${ }^{2}$ Department of Entomology, Faculty of Agriculture, Tarbiat Modares University, 14115-336 Tehran, Iran \\ ${ }^{3}$ Queensland Museum, PO Box 3300, South Brisbane 4101, Australia
}

Received 21 June 2021, Accepted 4 October 2021, Published online 5 November 2021

\begin{abstract}
In this study, we conducted a summer sampling of carabid beetles in eastern Australia to identify their associated parasitic mites. Here, we describe three new species of the genus Eutarsopolipus from under the elytra (forewings) of three native carabid species (Coleoptera: Carabidae): Eutarsopolipus paryavae n. sp. (pterostichi group) from Geoscaptus laevissimus Chaudoir; Eutarsopolipus pulcher n. sp. (leytei group) from Gnathaphanus pulcher (Dejean); and Eutarsopolipus chlaenii n. sp. (myzus group) from Chlaenius flaviguttatus Macleay. We further provide an identification key of the world species of pterostichi and leytei species groups as well as closely related species of the myzus group possessing similar characters including short cheliceral stylets. The significant diversity of Eutarsopolipus recovered here suggests that the current knowledge about Australian podapolipid mites (specially Eutarsopolipus) is still in its infancy and deserves further study.
\end{abstract}

Key words: Acari, Biodiversity, Trombidiformes, Carabidae, Symbiosis, Systematics.

Résumé - Vivre à l'abri sous les élytres : trois nouvelles espèces d'Eutarsopolipus (Acari, Heterostigmatina, Podapolipidae) parasitant des carabes australiens. Dans cette étude, nous avons effectué un échantillonnage estival de carabes dans l'est de l'Australie pour identifier leurs acariens parasites associés. Nous décrivons trois nouvelles espèces du genre Eutarsopolipus sous les élytres (ailes antérieures) de trois espèces de carabes indigènes (Coleoptera : Carabidae) : Eutarsopolipus paryavae n. sp. (groupe pterostichi) de Geoscaptus laevissimus Chaudoir, Eutarsopolipus pulcher n. sp. (groupe leytei) de Gnathaphanus pulcher (Dejean) et Eutarsopolipus chlaenii n. sp. (groupe myzus) de Chlaenius flaviguttatus Macleay. Nous fournissons en outre une clé d'identification des espèces mondiales des groupes d'espèces pterostichi et leytei ainsi que des espèces étroitement apparentées du groupe myzus possédant des caractères similaires, y compris des stylets chélicéraux courts. La diversité importante des Eutarsopolipus collectés ici suggère que les connaissances actuelles sur les acariens podapolipidés australiens (en particulier Eutarsopolipus) en sont encore à leurs balbutiements et méritent une étude plus approfondie.

\section{Introduction}

Beetles are among the most successful animals on the planet, accounting for about $25 \%$ of described species [10, 46]. Their success is partly attributed to their modified, sclerotized forewings, known as elytra, that protect their body against physical damage, desiccation, predation and thermal stress, enabling them to occupy a wide range of ecological niches [33, 48]. The subelytral space serves as a suitable microhabitat for a broad range of organisms such as mites, pseudoscorpions and

*Corresponding author: a. katlav@westernsydney. edu. au ${ }^{a}$ Dr. Hamidreza Hajiqanbar died on October 18, 2021, at the age of 48, when this paper was in press. This article is dedicated to the memory of Dr. Hamidreza Hajiqanbar, who cherished research as his life joy and made a major contribution to the world's insect-associated mites. nematodes that occupy this niche temporarily or permanently $[6,36,37]$. Some mites have evolved to be permanent ectoparasites in the subelytral spaces of beetles, imbibing beetle haemolymph using piercing stylets [2, 7]. This parasitic association sometimes occurs in one part of a mite's life cycle. For example, in Parasitengona (Acariformes: Prostigmata), larvae are parasites of many insects and are sometimes found under the elytra of terrestrial and aquatic beetles, while the nymphs and adults are free-living predators of immature stages of small arthropods [51, 52]. However, some taxa represent evolutionary transitions from phoresy towards parasitism, as in a few canestrinioid mites (Astigmata) in which deutonymphs remain phoretic on the thoracic venter of some carabid beetles, whereas the other stages (feeding stages) are subelytral parasites of the same hosts $[15,49]$. Some other groups are real parasites with 
their abbreviated life stages all occurring on the host's body surface [47]. Such subelytral parasitic associations with beetles have evolved independently in many Astigmata (e.g. most members of Canestrinioidea), Mesostigmata (e.g. several members of Gamasina) and Prostigmata (e.g. several members of Raphignathina and Heterostigmatina) [14, 16, 35, 38].

The cohort Heterostigmatina (Acariformes: Prostigmata) is a large group of morphologically diverse mites, among which numerous species are associated with arthropods [49]. Some species are subelytral symbionts of various beetles with their associations varying from facultative or obligate phoresy to parasitoidism or parasitism [25, 28, 30, 31]. Several species are potential biocontrol agents against pest beetles. For example, the species of the families Pyemotidae and Acarophenacidae are known as insect ectoparasitoids, with the former mostly attacking juvenile stages of bark beetles and stored-product beetles and the latter egg ectoparasitoids of various beetle families [8, 25, 29, 50].

All members of the family Podapolipidae are specialized obligate external (and rarely internal) parasites of various insects [18], among which at least 20 genera are subelytral ectoparasites of different beetle families, mainly Carabidae, Chrysomelidae, Coccinellidae, and Scarabaeidae [21, 23, 38, 45]. These mites are sexually transmitted, i.e. the motile stages of the mite (larvae or adult females) move from one host individual to another during copulation [17]. Parasitisation with these mites can negatively affect host fitness. For example, in some ladybirds, individuals parasitised with Coccipolipus suffer lower fecundity and egg viability [17] and sometimes reduced longevity [40]. Beyond this, these mites can modify host sexual and behavioural traits to boost their transmission success among individual hosts [1]. For example, in the milk weed leaf beetle, males parasitized by Chrysomelobia tend to more frequently contact other males, and are more successful in mating competition compared to unparasitised males; and this facilitates the mite's higher transmission rate [1].

Four genera of Podapolipidae are exclusively associated with carabid beetles: Dorsipes (22 species), Eutarsopolipus (99 species), Ovacarus (3 species) and Regenpolipus (5 species) [11, 13, 19, 26, 27, 44]. Apart from Ovacarus, which is an endoparasite of the reproductive tracts of some carabids, the rest are subelytral ectoparasites [11]. Species of Eutarsopolipus are versatile in morphology and are currently grouped into ten species groups [42]. Most of the species are specific to a single host species. However, a few parasitize more than one host species [41] or more rarely more than one genus [26], yet the possibility of them being cryptic species remains untested. More interestingly, in some cases more than one species can parasitize one host species [42] and sometimes they are specialized to different microhabitats such as the elytral cavity, on hindwings or on the dorsal abdomen of their host [39].

Australia is anticipated to harbour rich Eutarsopolipus fauna given its large diversity of carabid beetles [5]. This is inferred from small sampling efforts that have recently been conducted in some regions, and yet that discovered a considerable number of new species [31, 41-44]. Here, we describe three new species of Eutarsopolipus belonging to three different species groups (leytei, myzus, pterostichi) from three native Australian carabid beetles, raising the total number of Australian Eutarsopolipus to 30 species. All these species were recovered following a minimal sampling effort at one site, again corroborating the hypothesis that Australia is home to diverse podapolipid fauna awaiting discovery.

\section{Materials and methods}

Carabid host beetles were collected at night on the ground, near an outdoor LED solar light lamp in Richmond, New South Wales, in February 2020. The subelytral area of the beetles (preserved in 75-80\% ethanol) was subsequently examined for mite infestation. Mite specimens were cleared in a mixture of Nesbitt's fluid and a small amount of glycerine slide mounted in Hoyer's medium. Mite morphology was studied using a light microscope (Olympus BX51) equipped with phase contrast illumination. Mites from Queensland specimens of the carabid host Gnathaphanus pulcher were removed from dried beetles as described in Seeman [42] and examined using a Nikon 80 i microscope equipped with differential interference contrast. All measurements are given in micrometres for holotypes and the range of measurements for five selected paratypes (in parentheses), if available. Distances between setae were measured from the base of one seta to the other; setae with their acetabulum remnant only were categorised as vestigial setae and those with their setae not extending past the acetabulum as microsetae (m). Terminology and setal notation were adapted from Lindquist [32]. The species group assignment follows that of Seeman [42]. Host beetles were all identified with the help of Geoff Monteith.

\section{Abbreviations \\ ap \\ apodem \\ appr prosternal apodeme \\ apsej sejugal apodeme \\ QM Queensland Museum, QLD, Australia \\ ANIC Australian National Insect Collection; Canberra, ACT, Australia \\ AC-DE-TMU The Acarological Collection, Department of Ento- mology, Faculty of Agriculture, Tarbiat Modares University, Tehran, Iran}

\section{Results}

Family Podapolipidae Ewing, 1922

Genus Eutarsopolipus Berlese, 1913

Type species: Tarsopolipus lagenaeformis Berlese, 1911, by original designation.

Species group: pterostichi - Key characters of the group based on adult female: stigmata and tracheae absent; genua II-III without setae [42].

\section{Eutarsopolipus paryavae Katlav \& Hajiqanbar n. sp. (Figs. 1-3)}

urn:Isid:zoobank.org:act:36B8618D-FA09-474C-B4C32613DD962A5B

Type material: Total material recovered: $q(n=4)$, $\hat{o}(n=15)$, larval $+(n=4)$, ex. under elytra, on the base of membranous hind wing of one specimen of Geoscaptus 


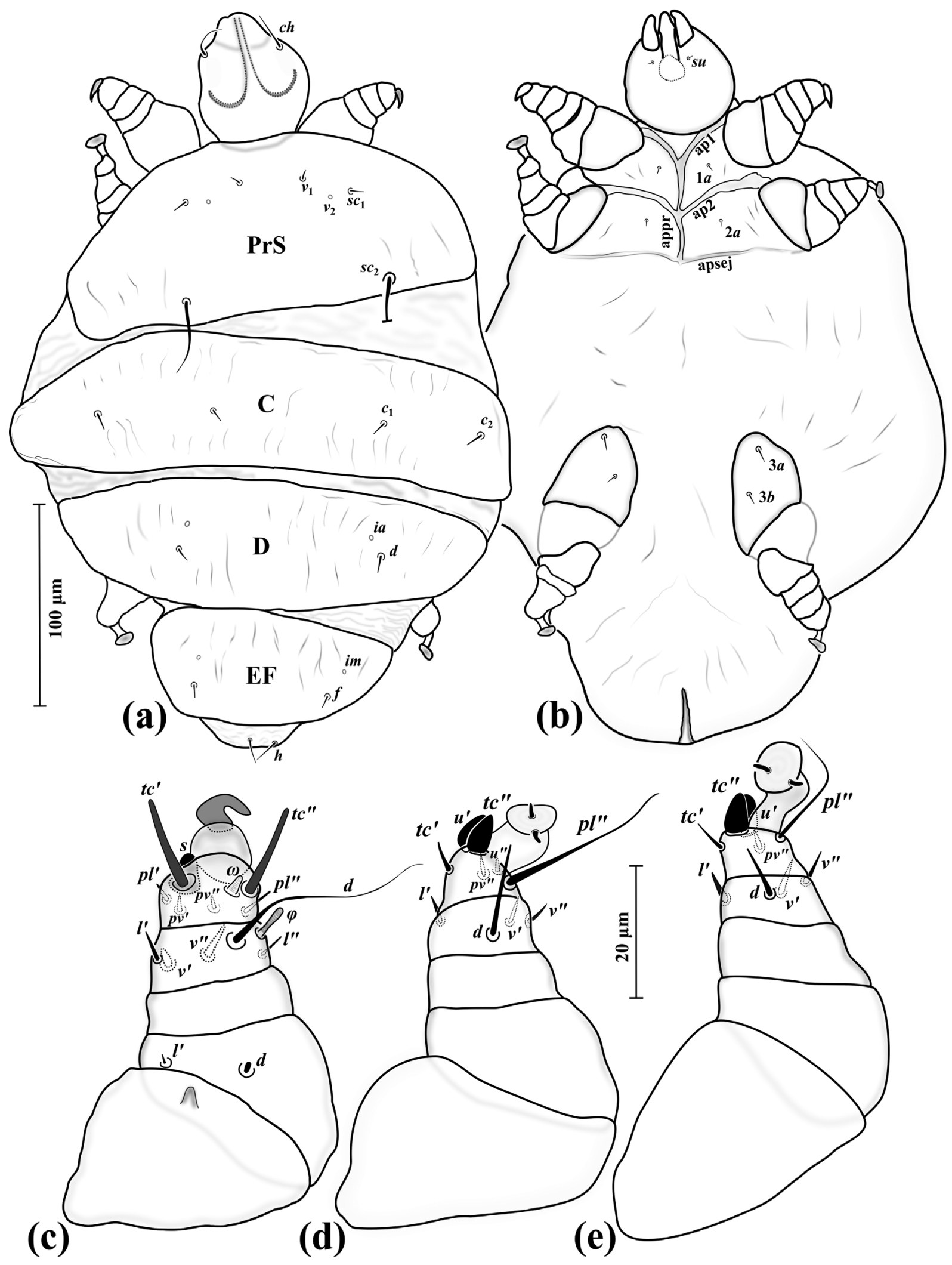

Figure 1. Eutarsopolipus paryavae n. sp. (adult female). (a) Body dorsum; (b) body venter; (c) right leg I; (d) ventral view of tarsus I; (e) right leg II; (f) right leg III. All legs in dorsal view. 

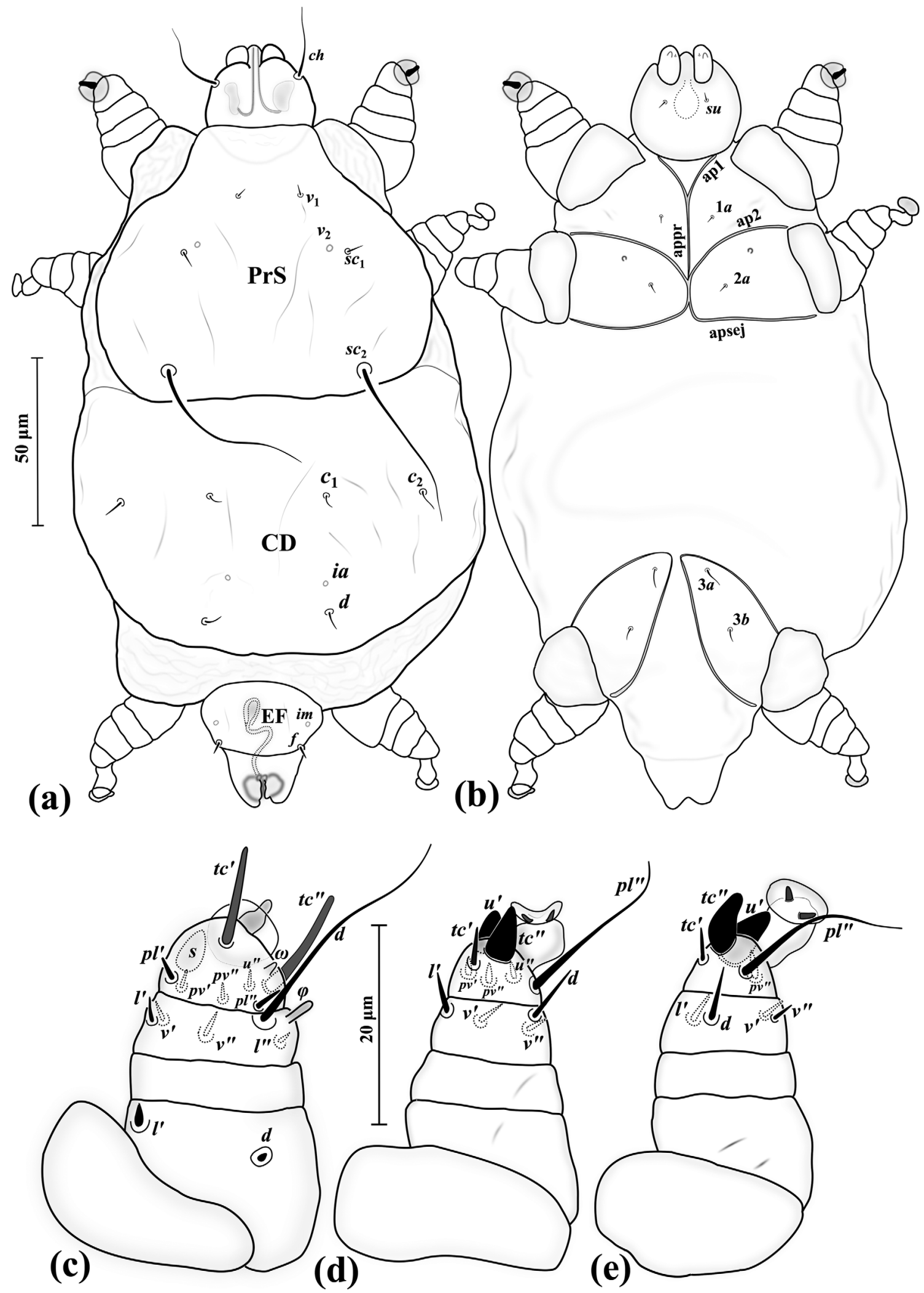

Figure 2. Eutarsopolipus paryavae n. sp. (male). (a) Body dorsum; (b) body venter; (c) right leg I; (d) right leg II; (e) right leg III. All legs in dorsal view. 


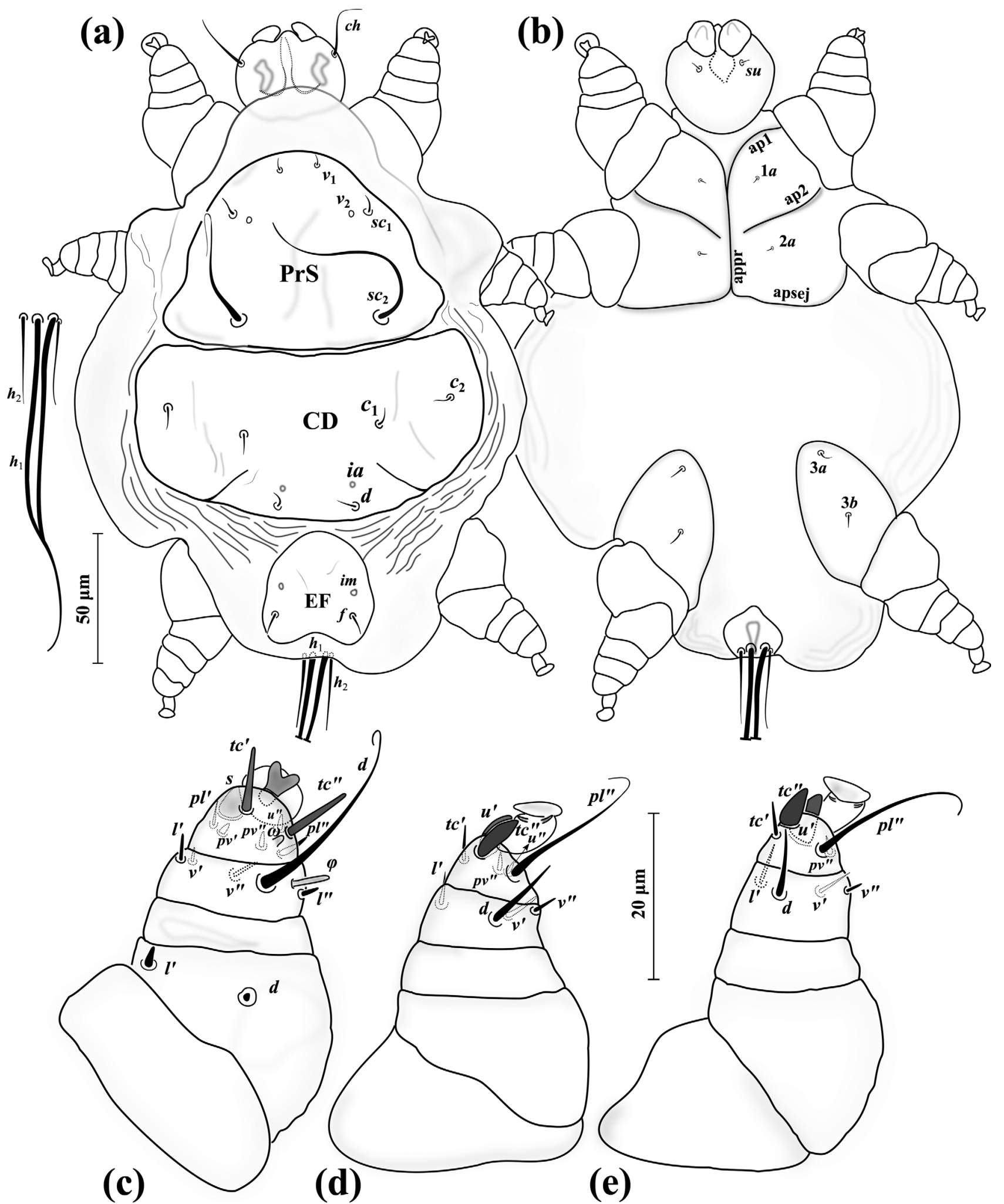

Figure 3. Eutarsopolipus paryavae n. sp. (larval female). (a) Body dorsum; (b) body venter; (c) right leg I; (d) right leg II; (e) right leg III. All legs in dorsal view.

laevissimus Chaudoir, 1855 (Coleoptera: Carabidae: Scaritinae). Holotype: adult female (ANIC 52-003953), ex. under elytra, on the base of membranous hind wing of $G$. laevissimus;
Coll. Shams Paryav; 11 Feb 2020. Paratypes: adult female $(n=3)$, male $(n=5)$ and larval female $(n=4)$, same data as holotype. 
Type locality: Loc. Vines Drive, Hawkesbury Campus, Western Sydney University, Richmond, NSW, 3336'45.6" S $150^{\circ} 44^{\prime} 40.2^{\prime \prime} \mathrm{E}$.

Deposition of type material: The holotype, one adult female, 2 male and 2 larval female paratypes are deposited at ANIC (ANIC 52-003953-58). 1 adult female, 2 males and 1 larval female paratypes are deposited at QM (QMS 117000-04). The remaining paratypes (TMU SP-20200211, 1-3), 10 non-type males and the host beetle specimen are deposited at AC-DETMU.

Etymology: The new species is named after the first author's mother, Shams Paryav, the collector of the host beetle samples, in gratitude of her immense engagement in material collections.

Authorship: Note that the authors of the new taxon are different from the authors of this paper; Article 50.1 and Recommendation 50A of International Code of Zoological Nomenclature [24].

\section{Description}

\section{Adult female (Fig. 1) $(n=4)$}

Gnathosoma (Figs. 1a-1b). Length 68 (72-86), width 58 (60-68); cheliceral stylets length 66 (63-68); pharynx length 14 (15-18), pharynx width 13 (13-14); ch 19 (21-26), su 3 (4-5); distance between setae ch-ch 34 (40-42), su-su 17 (19-22).

Idiosoma (Figs. 1a-1b). Length 300 (390-475), width 250 (295-335).

Idiosomal dorsum (Fig. 1a). All dorsal setae needle-like except attenuating setae $s c_{2}$; prodorsal plate $(\operatorname{PrS})$ with setae $v_{1} 5$ (4-5), $v_{2}$ vestigial, $s c_{1} 8$ (7-8), sc 36 (35-38). Plate C setae $c_{1} 8$ (9-10), $c_{2} 9$ (9-11). Plate D setae $d 9$ (8-9); cupuli $i a$ anterolaterad setae $d$. Plate EF setae $f 7$ (7-8); cupuli im anterolaterad setae $f$. Plate $\mathrm{H}$ not evident; setae $h 12$ (9-11). Distances between setae: $v_{1}-v_{1} 30$ (31-35), $v_{2}-v_{2} 61$ (62-69), $v_{1}-v_{2} 19$ (21-25), $s c_{1}-s c_{1} 74$ (76-87), $v_{1}-s c_{1} 27$ (27-31), $s c_{2}-s c_{2} 103$ (113-125), $s c_{1}-s c_{2} 49$ (51-56), $c_{1}-c_{1} 85$ (91-99), $c_{1}-c_{2} 49$ (58-63), $d-d 101$ (104-107), $f-f 67$ (70-74), $h_{1}-h_{1}$ 11 (14-18).

Idiosomal venter (Fig. 1b). All coxal plates smooth; all coxal setae tiny needle-like; ap1-2 well developed, both reaching to appr; coxisternal field I with setae $1 a 3$ (3-4) and coxisternal field II with $2 a 4$ (3-4); alveoli of setae $1 b$ and $2 b$ not evident; coxisternal field III with setae $3 a 7$ (7-8) slightly longer than $3 b 5$ (5-6). Distances between setae: $1 a-1 a$ 25 (26-35), 2a-2a 30 (31-45), 3a-3b 21 (23-28).

Legs (Figs. 1c-1e). Setal formula for legs I-III (femur-

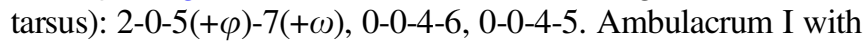
well-developed sickle-shaped claw, ambulacrum II-III each with a pair of tiny claws. Leg $I$ (Fig. 1c): femur, $d$ microseta, slightly thickened, seta $l^{\prime} 1$ (m-1); tibia, $\varphi 5$ (6-7) clubbed, $d 33$ (29-35), $l^{\prime} 4$ (4-5), $l^{\prime \prime} 4$ (4-6), $v^{\prime} 3$ (4-5) and $v^{\prime \prime} 5$ (5-6) slightly thickened, seta $k$ absent; tarsus, $\omega 3$ (3-4) digitiform, eupathidial setae $t c^{\prime} 14(13-16)$ and $t c^{\prime \prime} 14$ (14-15) distinctly blunt-ended, $p l^{\prime} 3$ (3-5), $p l^{\prime \prime} 5$ (5-6), setae $p v^{\prime} 2$ (2-3) and $p v^{\prime \prime} 2$ (2) slightly thickened, seta $s 6$ (6-7) blunt spur-like, $u^{\prime \prime}$ and $p^{\prime}$ not evident. Leg II (Fig. 1d): tibia, $d 14$ (10-13), $l^{\prime} 4$ (4-5), v' 5 (5-6), $v^{\prime \prime} 4$ (4-4); tarsus, $t c^{\prime} 5$ (5-6), setae $u^{\prime} 6$ (7-8) and $t c^{\prime \prime} 6(6-7)$ blunt spur-like, $p l^{\prime \prime} 28$ (21-25), $p v^{\prime \prime} 4$ (4-5), $u^{\prime \prime} 2$ (2). Leg III (Fig. 1e): tibia, $d 8$ (7-9), $l^{\prime} 5$ (4-4), $v^{\prime} 5$ (5-6), $v^{\prime \prime} 5$ (5); tarsus, $t c^{\prime} 5$ (5), setae $u^{\prime} 6$ (6-7) and $t c^{\prime \prime} 6$ (6) blunt spur-like, $p l^{\prime \prime} 20$ (22-24), $p v^{\prime \prime} 3$ (4-4).

\section{Male (Fig. 2) $(n=5)$}

Gnathosoma (Figs. 2a-2b). Length 33-36, width 32-33; cheliceral stylets length 23-26; pharynx length 9-10, pharynx width 7-8; ch 17-21, su 3-4; distance between setae ch-ch 25-26, su-su 12-14.

Idiosoma (Figs. 2a-2b). Length 145-210, width 120-130.

Idiosomal dorsum (Fig. 2a). All dorsal setae short (except $s c_{2}$ ) and pointed; $\operatorname{PrS}$ with setae $v_{1} 2-3, v_{2}$ vestigial, $s c_{1} 4-6$, setae $s c_{2}$ 52-65 attenuate. Plate $C D$ with seta $c_{1} 4-5, c_{2} 6-7$, $d$ 5-6; cupuli ia anterior to setae $d$. Plate EF setae $f 3-4$; cupuli im anterolaterad setae $f$. Genital capsule length 31-34, width 25-30, situated posterior to margin of EF, setae $h_{1}$ barely visible in few specimens. Distances between setae: $v_{1}-v_{1}$ $18-22, \quad v_{2}-v_{2} 40-43, \quad v_{1}-v_{2}$ 18-20, $s c_{1}-s c_{1} \quad 50-55, \quad v_{1}-s c_{1}$ $20-22, s c_{2}-s c_{2}$ 61-65, $s c_{1}-s c_{2}$ 37-41, $c_{1}-c_{1} \quad 36-45, c_{1}-c_{2}$ 29-40, $d-d$ 38-40, f-f 21-25.

Idiosomal venter (Fig. 2b). All coxal plates smooth; all coxal setae pointed; ap1-2 and apsej well developed, all fused with appr; coxisternal field I with setae $1 a 2$, alveoli $1 b$ not evident; coxisternal field II with $2 a 3-3$, alveoli $2 b$ evident; coxisternal field III with setae $3 a$ 5-6 slightly longer than $3 b$ 4-4. Distances between setae: $1 a-1 a$ 15-19, $2 a-2 a$ 23-27, 3a-3b 19-20.

Legs (Figs. 2c-2e). Setal formula for legs I-III (femur-

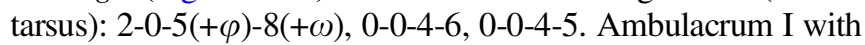
well-developed claw, ambulacrum II-III each with a pair of tiny claws. Leg I (Fig. 2c): femur, $d$ microseta, slightly thickened, seta $l^{\prime} 2-2$ thickened; tibia, $\varphi$ 4-5 clubbed, $d$ 24-26, $l^{\prime} 3$, $l^{\prime \prime} 1-2, v^{\prime} 2-3, v^{\prime \prime} 3-4$, seta $k$ absent; tarsus, $\omega 2$ tiny, coneshaped; eupathidial setae $t c^{\prime} 10-12$ and $t c^{\prime \prime} 11-12$ distinctly blunt-ended, setae $p l^{\prime}$ 3-4 and $p l^{\prime \prime}$ 3-4 slightly blunt-ended, $p v^{\prime} 2, p v^{\prime \prime} 2-2$, seta $s$ 4-5 blunt spur-like, $u^{\prime \prime} 1-2$, seta $p^{\prime}$ not evident. Leg II. (Fig. 2d): tibia, $d$ 5-7, $l^{\prime} 3-5, v^{\prime} 3-4, v^{\prime \prime} 2-3$; tarsus, seta $t c^{\prime} 4-5$, slightly blunt-ended; setae $u^{\prime}$ 5-6 and $t c^{\prime \prime} 5-6$ blunt spur-like, $p l^{\prime \prime}$ 19-20, $p v^{\prime \prime}$ 2-3, $u^{\prime \prime}$ 1-2. Leg III (Fig. 2e): tibia, $d 5-6, l^{\prime} 3, v^{\prime} 3, v^{\prime \prime} 3-3$; tarsus, $t c^{\prime} 3-4$ slightly blunt-ended, setae $u^{\prime}$ 6-7 and $t c^{\prime \prime}$ 5-6 blunt spur-like, $p l^{\prime \prime}$ 18-20, $p v^{\prime \prime} 3$.

\section{Larval female (Fig. 3) $(n=4)$}

Gnathosoma (Figs. 1a-1b). Length 35-39, width 41-42; cheliceral stylets length 30-33; pharynx length 10-12, pharynx width 9-11; ch 21-24, su 3-4; distance between setae ch-ch 35-38, su-su 16-17.

Idiosoma (Figs. 3a-3b). Length 220-235, width 135-175.

Idiosomal dorsum (Fig. 3a). All dorsal setae pointed; PrS with setae $v_{1} 3-4, v_{2}$ vestigial, $s c_{1} 6-7, s c_{2} 65-75$. Plate $\mathrm{C}$ setae $c_{1} 6-9, c_{2} 7-9$. Plate D setae $d 6-8$; cupuli ia anterolaterad setae $d$. Plate EF setae $f 7-8$; cupuli im anterior to setae $f$. Plate $\mathrm{H}$ situated ventrally with setae $h_{1} 130-140, h_{2}$ 29-32. Distances between setae: $v_{1}-v_{1} 13-16, v_{2}-v_{2}$ 39-40, $v_{1}-v_{2}$ 20-23, $s c_{1}-$ $s c_{1} 51-53, v_{1}-s c_{1}$ 26-27, $s c_{2}-s c_{2}$ 53-55, $s c_{1}-s c_{2} 40-41, c_{1}-c_{1}$ $49-53, c_{1}-c_{2}$ 29-32, $d-d$ 28-29, f-f 28-31. 
Idiosomal venter (Fig. 3b). All coxal plates smooth; all coxal setae tiny needle-like; ap1 and apsej well developed, both fusing to appr; ap2 not reaching to appr; coxisternal field I with setae $1 a 2-3$, alveoli $1 b$ not evident; coxisternal field II with 2a 2-3, alveoli $1 b$ not evident; coxisternal field III with setae $3 a$ 5-6 and $3 b$ 5-6 subequal. Distances between setae: $1 a-1 a$ 17-22, 2a-2a 24-28, 3a-3b 24-27.

Legs (Figs. 3c-3e). Setal formula for legs I-III (femur-

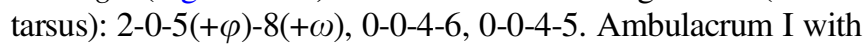
well-developed bifid claw with blunt tips, ambulacrum II-III each with a pair of barely discernible claws. Leg I (Fig. 3c): femur, $d$ microseta, slightly thickened, seta $l^{\prime} 2-3$ slightly thickened; tibia, $\varphi$ 5-5 baculiform, $d$ 27-30, setae $l^{\prime} 4$ and $l^{\prime \prime} 2-3$ slightly blunt-ended, $v^{\prime} 2-3, v^{\prime \prime} 4-5$, seta $k$ absent; tarsus, $\omega$ 2-2 cone-shaped with blunt tip, eupathidial setae $t c^{\prime} 10-12$ and $t c^{\prime \prime} 9$ distinctly blunt-ended, $p l^{\prime} 3-4, p l^{\prime \prime}$ 4-5, setae $p v^{\prime}$ 2-2 and $p v^{\prime \prime} 2-3$ slightly thickened, seta $s 5$ blunt spur-like, $u^{\prime \prime}$ 2, seta not evident. Leg II. (Fig. 3d): tibia, d 10-12, $l^{\prime}$ 4-5, $v^{\prime} 4-5, v^{\prime \prime} 3-4$; tarsus, $t c^{\prime}$ 5-5, setae $u^{\prime}$ 5-7 and $t c^{\prime \prime}$ 5-7 blunt spur-like, $p l^{\prime \prime}$ 20-23, $p v^{\prime \prime}$ 2-3, $u^{\prime \prime}$ 2. Leg III (Fig. 3e): tibia, $d$ 9-10, $l^{\prime} 5-6, v^{\prime} 5, v^{\prime \prime}$ 2-3; tarsus, $t c^{\prime} 4-5$, setae $u^{\prime}$ 6-7 and $t c^{\prime \prime}$ 5-6 blunt spur-like, $p l^{\prime \prime}$ 20-23, $p v^{\prime \prime} 2-3$.

\section{Differential diagnosis}

Within the pterostichi species group, the new species is most similar to E. fischeri Husband, 1998 and E. teteri Husband \& Husband, 2009 in having ambulacra II and III with a pair of claws each and ambulacra I with one claw and femur I with two setae. However, it differs from both species in having cheliceral stylets longer than 60 (vs. shorter than 40 in both species), setae $h_{1}$ 9-12 (absent in E. teteri and microsetae in E. fischeri) and seta $k$ on tibia I absent (seta $k$ on tibia I present in both species). The setal counts alone mask further differences. In $E$. paryavae and $E$. fisheri, the setae on femur I are the tiny setae $d$ and $l^{\prime}$, but in E. teteri seta $l^{\prime}$ is absent and $v^{\prime \prime}$ is present. Another important difference is the absence of a solenidion on tarsus II, which is present in E. teteri and probably present in E. fischeri (present in male and larva, absent or obscured in females). All the important characters among these three species are compared for all life stages in Table 1 and a key to the world species of the pterostichi group of Eutarsopolipus (based on adult females) is presented in Figure 4.

Species group: leytei - Key characters of the group based on adult females: stigmata and tracheae present; ambulacral claws II-III present; genu II-III with setae [42].

\section{Eutarsopolipus pulcher Hajiqanbar \& Seeman}

\section{n. sp. (Figs. 5-8)}

\section{urn:Isid:zoobank.org:act:33189535-1D7E-4118-B46D- 7EA9AE8E0207}

Type material. Total material recovered: adult female $(n=12)$, male $(n=6)$, larval female $(n=13)$, ex. under elytra, on the base of membranous hind wing of specimens of Gnathaphanus pulcher (Dejean, 1829) (Coleoptera: Carabidae; Harpalinae). Four out of ca. 160 examined host specimens found parasitized (4\% prevalence). Samples were collected at four independent events on 14 Feb 2020, 26 Feb 2020,
30 Feb 2020 and 3 March 2020. Holotype: adult female (ANIC 52-003959), ex. under elytra, on the base of membranous hind wing of G. pulcher; Coll. Shams Paryav; 14 Feb 2020. Paratypes: adult female $(n=5)$, male $(n=5)$, larval female $(n=5)$, same data as holotype.

Type locality: Loc. Vines Drive, Hawkesbury Campus, Western Sydney University, Richmond, NSW, 3336 $45.6^{\prime \prime} \mathrm{S}$ $150^{\circ} 44^{\prime} 40.2^{\prime \prime} \mathrm{E}$.

Deposition of types: The holotype, one adult female, 2 male and 2 larval female paratypes are deposited at ANIC (ANIC 52003959-54). 2 adult female, 2 males and 1 larval female paratypes are deposited at QM (QMS 117005-10). The remaining paratypes (TMU SP-20200214, 1-3) and the host beetle specimen are deposited at AC-DE-TMU.

Other material examined: adult female $(n=21)$, male $(n=4)$, larval female $(n=3)$, ex. under elytra, on the base of membranous hind wing of $G$. pulcher (host registration number T137238), Loc. "Feez Creek" property entrance, QLD, $21^{\circ} 51^{\prime} 40^{\prime \prime}$ S $148^{\circ} 14^{\prime} 19^{\prime \prime}$ E; Coll. S. Wright \& C. Burwell; 9 Mar 2005 (QMS 117011-38). Adult female $(n=1)$, larval female $(n=2)$, same data except different beetle (host registration number T137239) (QMS 117039-41).

Etymology: The new species name "pulcher" is adopted after the species name of the carabid host beetle G. pulcher meaning "beautiful" in Latin that is associated with the beautiful metallic colouration patterns of elytra in this beetle. Furthermore, this epithet has a proper relevance to the beautiful trifurcate setae $u^{\prime}$ on tarsi II-III in adult females of the new mite species.

Authorship: Note that the authors of the new taxon are different from the authors of this paper; Article 50.1 and Recommendation 50A of International Code of Zoological Nomenclature [24].

\section{Description}

\section{Adult female (Fig. 5) $(n=6)$}

Gnathosoma (Figs. 5a-5b). Length 45 (42-50), width 40 (34-41); cheliceral stylets length 51 (44-48); pharynx length 18 (16-18), pharynx width 14 (13-16); ch 18 (19-25), su 13 (12-14); distance between setae ch-ch 24 (23-26), su-su 14 (14-16).

Idiosoma (Figs. 5a-5b). Length 350 (270-415), width 215 (180-290).

Idiosomal dorsum (Fig. 5a). All dorsal setae pointed; prodorsal plate $(\operatorname{PrS})$ with setae $v_{1} 13(11-14), v_{2}$ vestigial, $s c_{1} 11$ (9-13), sc 57 (51-60). Plate C setae $c_{1} 6$ (4-6), $c_{2} 6$ (4-6). Plate D setae $d 5$ (4-5); cupuli ia evident, anterolaterad setae $d$. Plate EF setae $f 5$ (4-5); cupuli im evident, anterolaterad setae $f$. Plate $\mathrm{H}$ and setae $h_{1}$ not evident. Distances between setae: $v_{1}-v_{1} 46$ (46-49), $v_{2}-v_{2} 51$ (49-59), $v_{1}-v_{2} 34$ (32-34), $s c_{1}-s c_{1} 76$ (74-80), $v_{1}-s c_{1} 27$ (27-29), $s c_{2}-s c_{2} 93$ (88-99), $s c_{1}-s c_{2} 70$ (68-71), $c_{1}-c_{1} 81$ (75-92), $c_{1}-c_{2} 54$ (49-54), $d-d$ 113 (102-112), f-f 83 (73-93).

Idiosomal venter (Fig. 5b). All coxal plates smooth; all coxisternal setae tiny needle-like; ap1-2 and apsej well developed, reaching to appr; coxisternal field I with setae $1 a$ 5 (5-6); alveoli of vestigial setae $1 b$ evident; coxisternal field II with $2 a 5$ (5-7); alveoli of vestigial setae $2 b$ evident; 
Table 1. Comparison of selected characters (range of measurements if available) of $E$. paryavae n. sp. (Ep) with two closely related species of the pterostichi species group: E. fischeri $(E f)$ and E. teteri $(E t)$. Dashes (-) denote absence of the character. Characters for which the data are obscured/not available in the original descriptions are given as question marks (?). Letters $\mathrm{v}$ and $\mathrm{m}$ indicate vestigial and mirosetae, respectively. Abbreviations: L. (length), S. (stylet), Gn. (gnathosoma), Gen. cap. (genital capsule), Ch. (chelicera), Sol. (solenidion), Ta (tarsus), Ti (tibia), Fe (femur).

\begin{tabular}{|c|c|c|c|c|c|c|c|c|c|}
\hline \multirow{2}{*}{$\begin{array}{l}\text { Life stage } \\
\text { Character }\end{array}$} & \multicolumn{3}{|c|}{ Female } & \multicolumn{2}{|c|}{ Male } & \multicolumn{4}{|c|}{ Larval female } \\
\hline & $E p$ & $E f$ & $E t$ & $E p$ & $E f$ & $E t$ & $E p$ & $E f$ & $E t$ \\
\hline Gn. L. & $68-86$ & $45-48$ & 45 & $33-36$ & $26-29$ & $29-32$ & $35-39$ & 31 & $35-38$ \\
\hline Ch. S. L. & $63-68$ & $33-34$ & 38 & $23-26$ & $19-22$ & 22 & $30-33$ & 22 & $32-34$ \\
\hline Setae $c h$ & $19-26$ & $17-19$ & 15 & $17-21$ & $2-4$ & 5 & $21-24$ & 17 & $20-25$ \\
\hline Setae $s u$ & $3-5$ & $5-6$ & 14 & $3-4$ & $2-3$ & 8 & $3-4$ & 3 & $10-12$ \\
\hline Setae $v_{1}$ & $4-5$ & $5-6$ & 10 & $2-3$ & 2 & $?$ & $3-44$ & 5 & 15 \\
\hline Setae $s c_{1}$ & $7-8$ & $6-7$ & 9 & 4-6 & 2 & $?$ & $6-7$ & 3 & $9-10$ \\
\hline Setae $s c_{2}$ & $35-38$ & $32-42$ & 59 & $52-65$ & 48 & $38-45$ & $65-75$ & 74 & 80 \\
\hline Setae $c_{1}$ & $8-10$ & $3-5$ & 5 & $4-5$ & 2 & $?$ & $7-9$ & 3 & $8-12$ \\
\hline Setae $c_{2}$ & $9-11$ & $5-6$ & 7 & $6-7$ & 2 & $?$ & $7-9$ & 4 & 10 \\
\hline Setae $d$ & $8-9$ & $3-5$ & 7 & $5-6$ & $?$ & $?$ & $6-8$ & 4 & 10 \\
\hline Setae $f$ & $7-8$ & 5 & 5 & $3-4$ & $?$ & $?$ & 7-8 & 4 & $7-10$ \\
\hline Setae $h_{1}$ & $9-12$ & $\mathrm{~m}$ & - & - & - & - & $130-140$ & 43 & $60-62$ \\
\hline Setae $h_{2}$ & - & - & - & - & - & - & 29-32 & 16 & $5-7$ \\
\hline Setae $1 a$ & $3-4$ & 2 & $\mathrm{~m}$ & 2 & $\mathrm{v}$ & $\mathrm{m}-3$ & $2-3$ & $\mathrm{~m}$ & 4 \\
\hline Setae $2 a$ & $3-4$ & $2-3$ & 7 & 3 & $\mathrm{v}$ & 3 & $2-3$ & $\mathrm{~m}$ & $5-6$ \\
\hline Setae $3 a$ & $7-8$ & $4-5$ & $?$ & $5-6$ & $\mathrm{v}$ & $?$ & $5-6$ & 3 & $?$ \\
\hline Setae $3 b$ & $5-6$ & 7 & 3 & 4 & $?$ & $\mathrm{~m}$ & $5-6$ & 4 & 5 \\
\hline Gen. cap. L. & - & - & - & $31-34$ & $25-38$ & 38 & - & - & - \\
\hline Gen. cap. W. & - & - & - & $25-30$ & $27-30$ & 32 & - & - & - \\
\hline Sol. Ta I $\omega$ & $3-4$ & 3 & 5 & 2 & $2-3$ & 5 & 2 & 3 & $4-5$ \\
\hline Sol. Ti I $\varphi$ & $5-7$ & $7-10$ & 7 & $4-5$ & $7-8$ & $5-7$ & $4-5$ & 6 & $8-13$ \\
\hline Sol. Ta II $\omega$ & - & $?$ & 5 & - & $2-3$ & 5 & - & 3 & 5 \\
\hline Fe I seta $v^{\prime \prime}$ & - & - & 15 & - & - & $10-18$ & - & - & 10 \\
\hline Fe I seta $l^{\prime}$ & $m-1$ & $\sim 3-4$ & - & 2 & $\sim 1$ & - & $2-3$ & $\sim 2$ & - \\
\hline Ta III seta $p l^{\prime \prime}$ & $20-24$ & $15-17$ & 15 & $18-20$ & 12 & $10-15$ & $20-23$ & 13 & $15-18$ \\
\hline
\end{tabular}

Adult females of pterostichi group

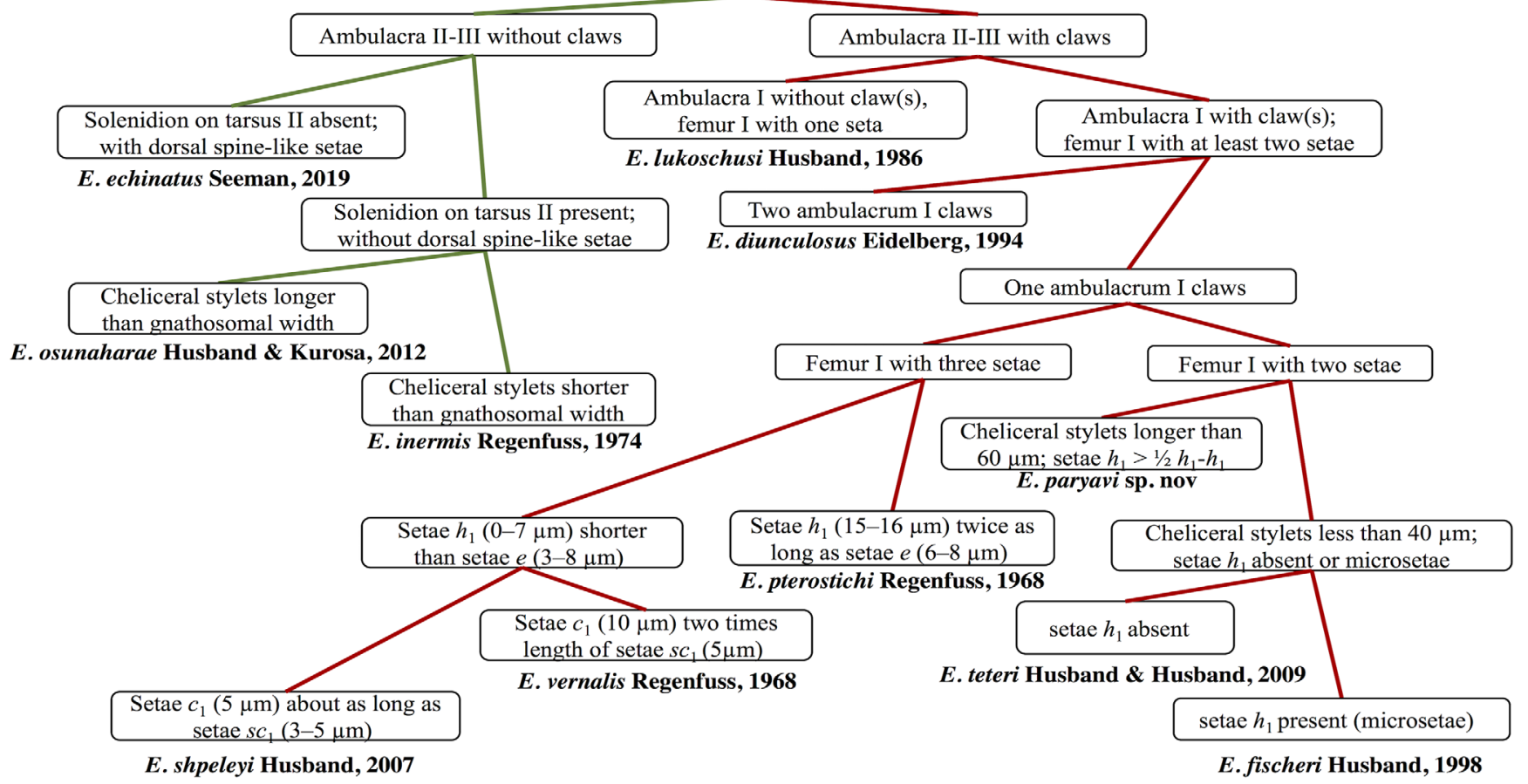

Figure 4. Key to the world species of Eutarsopolipus in the pterostichi group (based on adult females). 


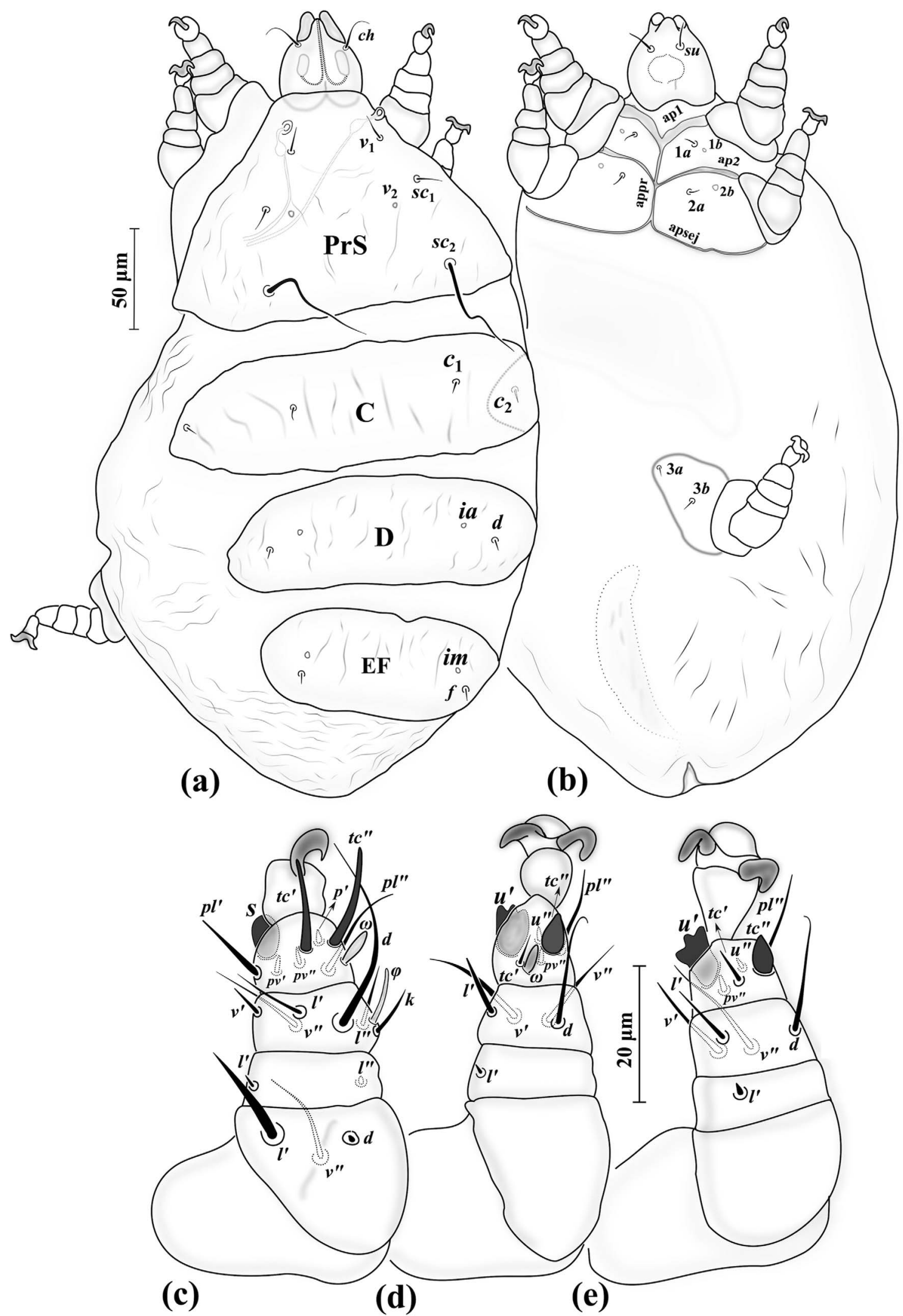

Figure 5. Eutarsopolipus pulcher n. sp. (adult female). (a) Body dorsum; (b) body venter; (c) right leg I; (d) ventral view of tarsus I; (e) right leg II; (f) right leg III. All legs in dorsal view. 


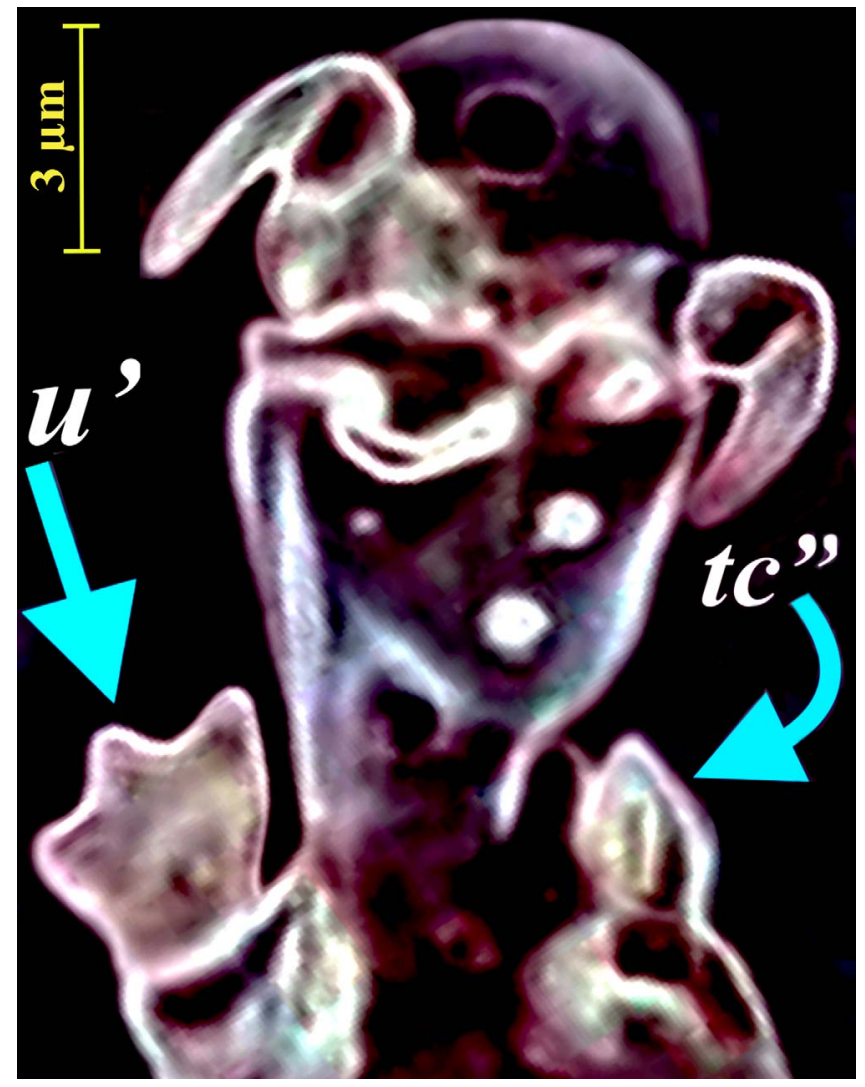

Figure 6. Phase-contrast micrograph of tarsus III in Eutarsopolipus pulcher $\mathrm{n}$. sp. (adult female) representing modified trifurcate seta $u^{\prime}$ and spur-like seta $t c^{\prime \prime}$.

coxisternal field III with setae $3 a 4$ (4-5) and $3 b 6$ (5-6). Distances between setae: $1 a-1 a \quad 31$ (29-35), $2 a-2 a \quad 34$ (36-42), 3a-3b 26 (22-27).

Legs (Figs. 5c-5e, 6). Setal formula for legs I-III (femurtarsus): $3-2-6(+\varphi)-8(+\omega), 0-1-4-6(+\omega), 0-1-4-6$. Ambulacrum I with sickle-shaped claw, ambulacrum II-III each with a pair of well-developed claws. Leg I (Fig. 5c): femur, $d$ microseta, seta $l^{\prime} 15(14-16)$ pointed and thickened, subequal to $v^{\prime \prime} 15$ (12-15); genu with tiny setae $l^{\prime} 2$ (2-2) and $l^{\prime \prime} 1$ (1-2); tibia with $\varphi 8$ (7-9) baculiform, $d 29$ (25-29), $l^{\prime} 11$ (9-11), $l^{\prime \prime} 9$ (7-9), $v^{\prime} 5$ (5-6) stiff, $v^{\prime \prime} 14$ (13-16), seta $k 8$ (8-10); tarsus I, $\omega 5$ (4-5) digitiform, eupathidial setae $t c^{\prime} 14(12-15)$ and $t c^{\prime \prime} 15$ (13-15) distinctly blunt-ended, $p l^{\prime} 11$ (11-13), $p l^{\prime \prime} 15$ (13-17), setae $p v^{\prime} 3(3-3)$ and $p v^{\prime \prime} 2(2-3)$ subequal, seta $s 6$ (6-7) modified and thickened, $p^{\prime} 2$ (2) slightly thickened. Leg II. (Fig. 5d): genu, $l^{\prime} 2$ (2); tibia, $d 17$ (15-17), $l^{\prime} 9$ (7-9), $v^{\prime} 14$ (12-14), $v^{\prime \prime} 15$ (13-19); tarsus II, $\omega 4$ (3-4) digitiform, $t c^{\prime} 5$ (5-7), setae $u^{\prime} 8$ (7-8) spine-like and trifurcate, $t c^{\prime \prime} 6(6-7)$ blunt spur-like, $p l^{\prime \prime} 13$ (12-13), $p v^{\prime \prime} 2$ (2-3), $u^{\prime \prime} 2$ (2). Leg III (Figs. 5e, 6): genu, $l^{\prime} 2$ (2-2); tibia, $d 17$ (15-18), $l^{\prime} 9$ (7-9), $v^{\prime} 14$ (13-14), $v^{\prime \prime} 17$ (15-18); tarsus III, $t c^{\prime} 5$ (5-7), setae $u^{\prime} 8$ (7-8) spine-like and trifurcate (Fig. 6), $t c^{\prime \prime} 6$ (5-6) blunt spur-like (Fig. 5f), $p l^{\prime \prime} 14$ (12-14), $p v^{\prime \prime} 2$ (2-3), $u^{\prime \prime} 14$ (12-14).

\section{Male (Fig. 7) $(n=5)$}

Gnathosoma (Figs. 7a-7b). Length 25-36, width 23-27; cheliceral stylets length 17-19; pharynx length 9-10, pharynx width 6-8; ch 8-12; su 9-10; distance between setae $c h-c h$ 17-20, su-su 12-13.

Idiosoma (Figs. 7a-7b). Length 140-160, width 105-115.

Idiosomal dorsum (Fig. 7a). All setae on dorsum microsetae (except $s c_{2}$ ); PrS with setae $v_{2}$ vestigial, setae $s c_{2}$ 34-46 attenuate and pointed. Plate CD with cupuli ia anterior to setae $d$. Plate EF setae with cupuli im anterolaterad setae $f$. Genital capsule length 23-30, width 28-33, situated posterior to margin of $\mathrm{EF}$, setae $h_{1}$ barely visible on genital capsule. Distances between setae: $v_{1}-v_{1} 18-19, v_{2}-v_{2} 30-33, v_{1}-v_{2} 18-19, s c_{1}-s c_{1}$ $44-47, v_{1}-s c_{1}$ 17-18, $s c_{2}-s c_{2} \quad 42-45, s c_{1}-s c_{2} \quad 26-28, c_{1}-c_{1}$ $39-43, c_{1}-c_{2}$ 25-29, $d-d$ 29-34, $f-f$ 19-21.

Idiosomal venter (Fig. 7b). All coxal plates smooth; all ventral setae on coxal area microsetae; ap1-2 well developed, fused with appr, apsej weekly developed, not reaching appr; alveoli of setae $1 b$ on coxisternal field I evident; on coxisternal field II alveoli of setae $2 b$ evident. Distances between setae: 1a-1a 17-19, 2a-2a 22-24, 3a-3b 18-20.

Legs (Figs. 7c-7e). Setal formula for legs I-III (femur-

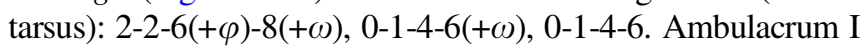
with a small claw, ambulacrum II-III each with a pair of small claws. Leg $I$ (Fig. 7c): femur, setae $d$ and $l^{\prime}$ microsetae; genu, setae $l^{\prime}$ and $l^{\prime \prime}$ microsetae; tibia, $\varphi$ 6-8 baculiform, $d$ 21-25, $l^{\prime}$ and $l^{\prime \prime}$ microsetae, $v^{\prime} 1, v^{\prime \prime} 12-14$, seta $k 3-5$; tarsus, $\omega 4-5$ digitiform; eupathidial setae $t c^{\prime} 8-10$ and $t c^{\prime \prime} 10-11$ distinctly blunt-ended, setae $p l^{\prime} 8-9$ and $p l^{\prime \prime}$ 10-12, seta $p v^{\prime} 1-1$ stiff and blunt-ended, $p v^{\prime \prime} 2-2$, seta $s$ 4-5 blunt spur-like, $p^{\prime} 1-1$. Leg II. (Fig. 7d): genu, $l^{\prime} 1$; tibia, $l^{\prime} 2, d$ 13-15, $v^{\prime} 11-14, v^{\prime \prime}$ 11-14; tarsus, $\omega$ 4-5 thickened and digitiform, seta $t c^{\prime} 4-5$, slightly blunt-ended, $u^{\prime}$ 4-6 spine-like and bifurcate, $t c^{\prime \prime} 4-5$ blunt spur-like, $p l^{\prime \prime}$ 9-11, $p v^{\prime} 2, p v^{\prime \prime} 2, u^{\prime \prime} 1$. Leg III (Fig. 7e): genu, $l^{\prime} 1$; tibia, $d$ 10-13, $l^{\prime} 1, v^{\prime} 1, v^{\prime \prime} 12-14$; tarsus, $t c^{\prime}$ 5-7 stiff and slightly blunt-ended, setae $u^{\prime}$ 5-6 spine-like and bifurcate, $t c^{\prime \prime} 4-5$ blunt spur-like, $p l^{\prime \prime} 9-10, p v^{\prime \prime} 1, u^{\prime \prime} 1$.

\section{Larval female (Fig. 8) $(n=5)$}

Gnathosoma (Figs. 8a-8b). Length 29-32, width 24-29; cheliceral stylets length 28-34; pharynx length 10-13, pharynx width 7-9; ch 20-25; su 10-12; distance between setae ch-ch 15-18, su-su 10-11.

Idiosoma (Figs. 8a-8b). Length 125-145, width 95-110.

Idiosomal dorsum (Fig. 8a). All dorsal setae needle-like except $s c_{2}$ which is long and attenuate; $\operatorname{PrS}$ with setae $v_{1} 11-13$, $v_{2}$ vestigial, $s c_{1} 10-12, s c_{2} 62-72$. Plate $\mathrm{C}$ setae $c_{1} 7-8, c_{2} 5-7$. Plate D setae $d 6-7$; cupuli ia anterolaterad setae $d$. Plate EF setae $f$ 7-9; cupuli im anterior to setae $f$. Plate $\mathrm{H}$ not evident; setae $h_{1}$ 64-66, $h_{2} \mathrm{~m}-2$. Distances between setae: $v_{1}-v_{1}$ $25-28, \quad v_{2}-v_{2}$ 35-37, $v_{1}-v_{2}$ 22-25, $s c_{1}-s c_{1} \quad 56-60, v_{1}-s c_{1}$ 23-26, $s c_{2}-s c_{2} 44-48, s c_{1}-s c_{2} \quad 30-32, c_{1}-c_{1} 25-28, c_{1}-c_{2}$ $31-34, d-d$ 22-25, $f-f 25-30$.

Idiosomal venter (Fig. 8b). All coxal plates smooth; all coxal setae tiny needle-like; ap1-2 well developed, both fusing to appr; apsej not evident; coxisternal field I with setae 1a 5-7; alveoli of setae $1 b$ on coxisternal field I evident; coxisternal field II with 2a 4-6; alveoli of setae $2 b$ evident; coxisternal field III with setae $3 a$ 5-6 and $3 b 5$ subequal. Distances between setae: $1 a-1 a$ 17-21, $2 a-2 a$ 16-22, 3a-3b 17-19.

Legs (Figs. 8c-8e). Setal formula for legs I-III (femur-

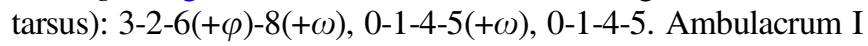


A. Katlav et al.: Parasite 2021, 28, 75
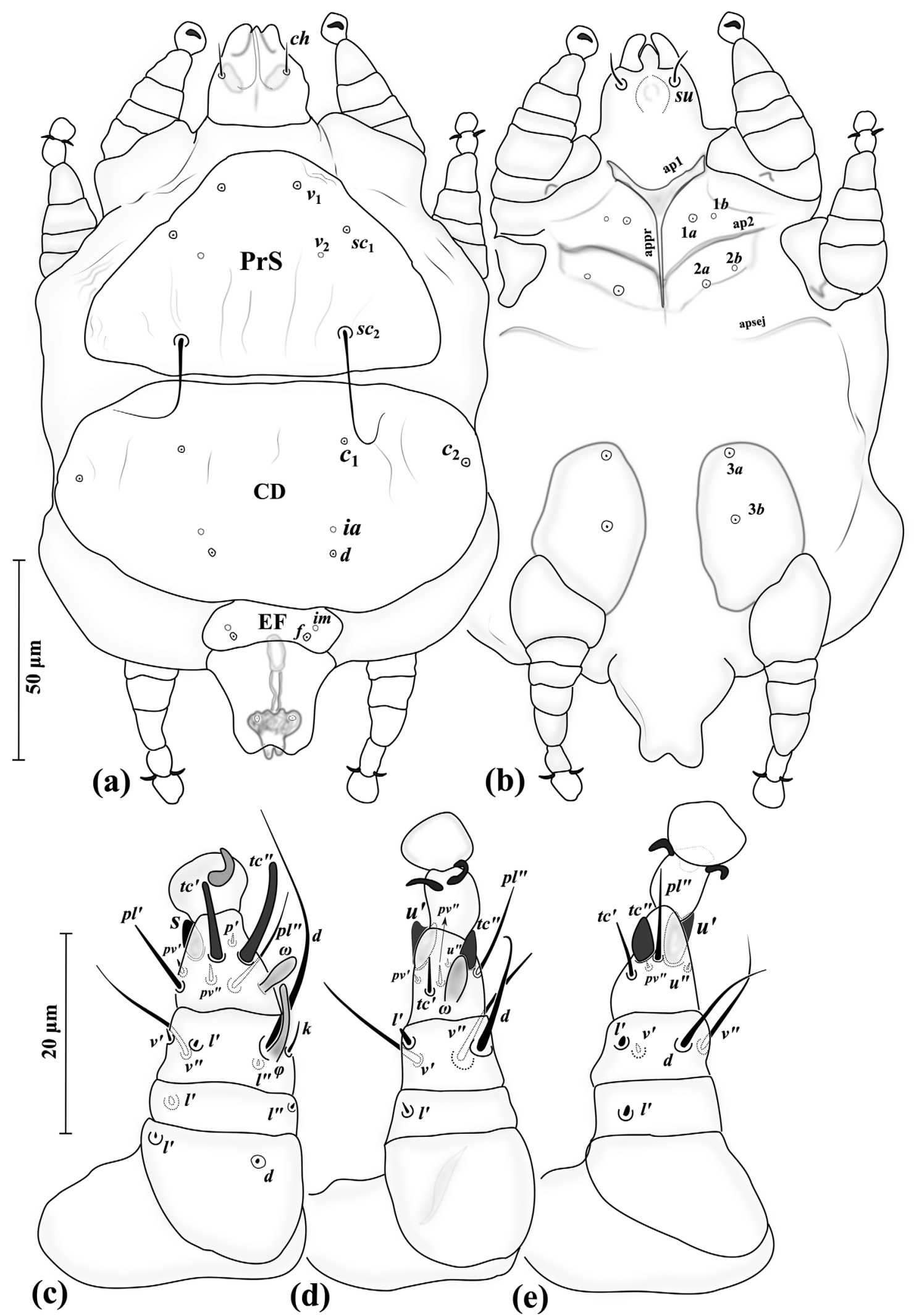

Figure 7. Eutarsopolipus pulcher n. sp. (male). (a) Body dorsum; (b) body venter; (c) right leg I; (d) right leg II; (e) right leg III. All legs in dorsal view. 


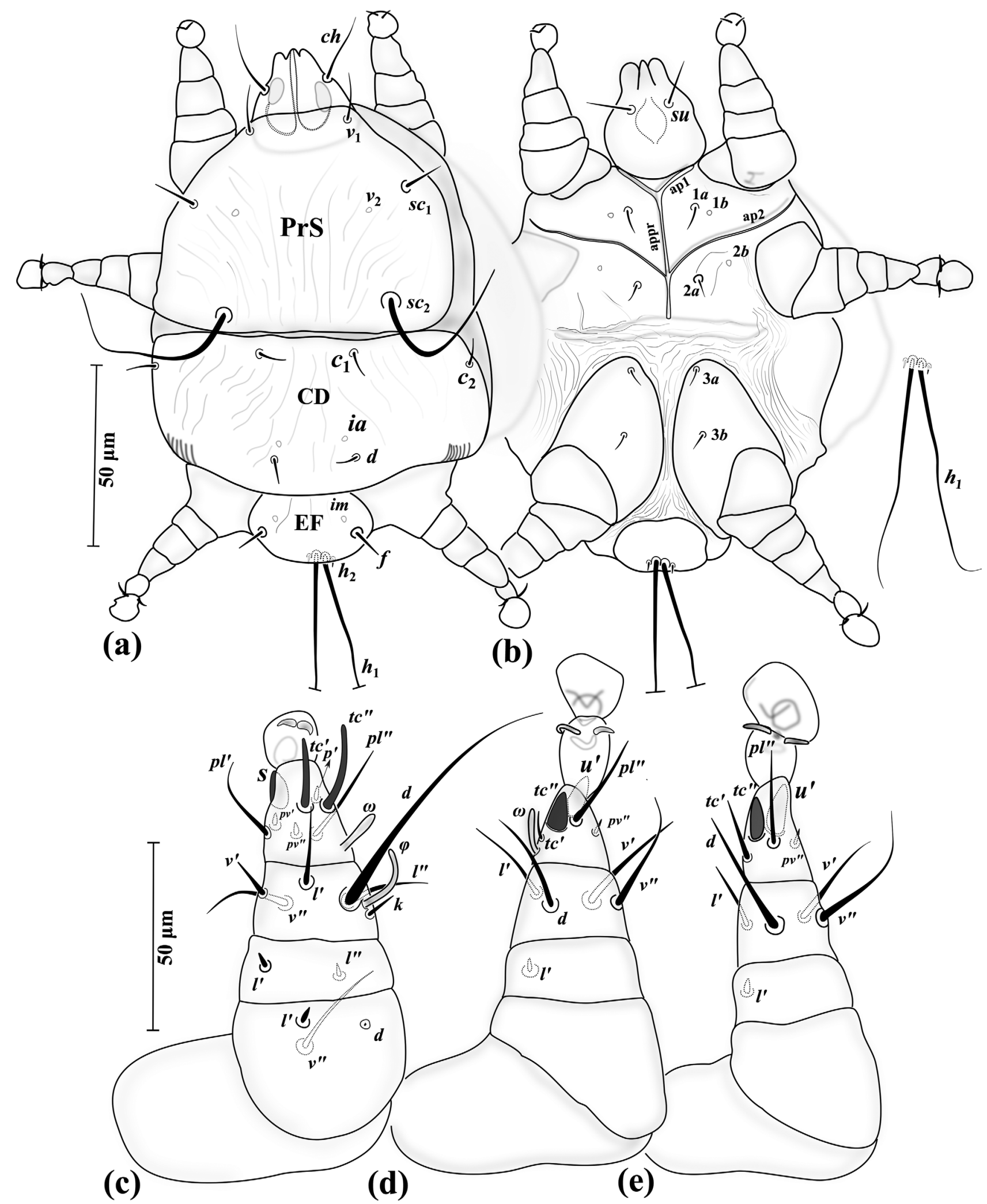

Figure 8. Eutarsopolipus pulcher n. sp. (larval female). (a) Body dorsum; (b) body venter; (c) right leg I; (d) right leg II; (e) right leg III. All legs in dorsal view.

with a small bifid claw, ambulacrum II-III each with a pair of small claws. Leg $I$ (Fig. 8c): femur, $d$ microseta, seta $l^{\prime} 2$ slightly thickened, $v^{\prime \prime} 10-11$; genu, $l^{\prime} 2$, $l^{\prime \prime} 1-1$; tibia, $\varphi$ 7-8 baculiform and bent, $d$ 28-30, setae $l^{\prime} 8-9$ and $l^{\prime \prime}$ 9-12, $v^{\prime}$ $4-5, v^{\prime \prime} 10-12$, seta $k 3-4$; tarsus, $\omega 4-5$ digitiform, eupathidial setae $t c^{\prime} 8-9$ and $t c^{\prime \prime}$ 9-10 distinctly blunt-ended, $p l^{\prime}$ 9-10, 
$p l^{\prime \prime} 12-14$, setae $p v^{\prime} 1-1$ and $p v^{\prime \prime} 1-2$, seta $s$ 3-5 blunt spur-like, $p^{\prime}$ 2. Leg II. (Fig. 8d): genu, $l^{\prime} 2$; tibia, $d$ 13-18, $l^{\prime}$ 10-11, $v^{\prime}$ 10-13, v" 13-15; tarsus, $\omega$ 4-5 digitiform, $t c^{\prime} 3-4$, setae $u^{\prime} 5$ and $t c^{\prime \prime}$ 4-5 blunt spur-like, $p l^{\prime \prime}$ 9-11, $p v^{\prime \prime} 2, u^{\prime \prime}$ not evident. Leg III (Fig. 8e): genu, $l^{\prime}$ 2; tibia, $d$ 14-15, $l^{\prime} 8-12, v^{\prime} 7-11$, $v^{\prime \prime} 11-12$; tarsus, $t c^{\prime}$ 6-7, setae $u^{\prime}$ 5-6 and $t c^{\prime \prime}$ 5-6 blunt spurlike, $p l^{\prime \prime} 10-11, p v^{\prime \prime} 2, u^{\prime \prime}$ not evident.

\section{Differential diagnosis}

This new species is unique in Eutarsopolipus by having trifurcate setae $u^{\prime}$ on tarsi II-III. However, among species with simple claws on legs I (unlike E. biuncatus Seeman, 2021 and $E$. janus Seeman, 2021 with bifurcate claws on legs I), it is most similar to E. leytei Husband \& Raros, 1989 with femur I seta $l^{\prime}$ very short, not reaching genual base in adult females; but it is readily distinguishable from this species by longer setae $v_{1}$ 11-14 ( $m-5$ in E. leytei) and shorter cheliceral stylets being at most 51 in E. pulcher n. sp. vs. 68 in E. leytei.

The new species further differs from $E$. dastych $i$ with setae $v_{1}$ longer than $c h$ and setae $c_{1}, c_{2}, d$ and $f$ shorter than 8 in adult females ( $v$ s. setae $v_{1}$ shorter than $c h$ and setae $c_{1}, c_{2}, d$ and $f$ longer than 15 in adult females of $E$. dastychi). The male of E. pulcher n. sp. resembles that of E. orpheus with all ventral and dorsal setae (except $s c_{2}$ ) being microsetae, but it differs from $E$. orpheus with setae $c h$ longer than 8 (ch microsetae in male of E. orpheus). The larval female of E. pulcher n. sp. is similar to E. orpheus with $h_{1}$ shorter than 70 and $h_{2}$ shorter than 2, but it is readily distinguishable from E. pulcher $\mathrm{n}$. sp. by shorter setae $s c_{1}, s c_{2}, c_{1}, c_{2}, d, 3 a$ and $3 b$ (Table 2). All the important characters among the species of leytei group are compared for all life stages (excluding E. leytei with unknown male) in Table 2 and keys to the world species (based on adult females) are presented in Figure 9.

Species group: myzus - Key characters of the group based on adult females: stigmata and tracheae present; ambulacral claws II-III present; genu I-III without setae; femur I with two setae [42].

\section{Eutarsopolipus chlaenii Katlav \& Hajiqanbar n. sp. (Figs. 10-11)}

urn:lsid:zoobank.org:act:25276820-D40C-4F2F-AAA2-

\section{E68575A38719}

Type material: Total material recovered: $\circ(n=4)$, larval o $(n=16)$, ex. under elytra, on the base of membranous hind wing of specimens of Chlaenius flaviguttatus Macleay, 1825 (Coleoptera: Carabidae: Harpalinae: Chlaeniini) (Fig. 13). Three out of four collected host specimens found parasitised. Beetles specimens were collected at three independent events on 24 Feb 2020, 26 Feb 2020, and 28 Feb 2020. Holotype: adult female (ANIC 52-003965), ex. under elytra, on the base of membranous hind wing of $C$. flaviguttatus; Coll. Shams Paryav; 24 Feb 2020. Paratypes: adult female $(n=3)$, larval female $(n=5)$, same data as holotype (24 Feb 2020, 26 Feb 2020, and 28 Feb 2020).

Type locality: Loc. Vines Drive, Hawkesbury Campus, Western Sydney University, Richmond, NSW, 3336 $45.6^{\prime \prime} \mathrm{S}$ $150^{\circ} 44^{\prime} 40.2^{\prime \prime} \mathrm{E}$.
Deposition of material: The holotype, one adult female and 2 larval female paratypes are deposited at ANIC (ANIC 52-003965-68). 1 adult female and 2 larval female paratypes are deposited at QM (QMS 117009-10, 117042). The remaining paratypes (TMU SP-20200224, 1-3), 11 non-type larval females and the host beetle specimen are deposited at AC-DE-TMU.

Etymology: The species epithet "chlaenii" refers to the generic name of the carabid host beetle Chlaenius flaviguttatus.

Authorship: Note that the authors of the new taxon are different from the authors of this paper; Article 50.1 and Recommendation 50A of International Code of Zoological Nomenclature [24].

\section{Adult female (Fig. 10) $(n=4)$}

Gnathosoma (Figs. 10a-10b). Length 45 (43-45), width 42 (40-42); cheliceral stylets length 28 (29-30); pharynx length 12 (12-13), pharynx width 12 (12-13); ch 15 (15-16), pointed; su 6 (5-6), needle-like; distance between setae ch-ch 27 (27-29), su-su 17 (16-17).

Idiosoma (Figs. 10a-10b). Length 230 (225-240), width 185 (165-185).

Idiosomal dorsum (Fig. 10a). Respiratory system (stigmata and tracheae) present, stigmata stalked; all dorsal setae pointed; prodorsal plate $(\mathrm{PrS})$ with setae $v_{1} 6(5-6)$, setae $v_{2}$ vestigial, setae $s c_{1} 5$ (5-6), $s c_{2} 42$ (38-41). Plate C setae $c_{1} 7$ (6-7), $c_{2} 5$ (6-6). Plate D setae $d 5$ (5-6); cupuli ia evident, anterolaterad setae $d$. Plate EF setae $f 7$ (6-7); cupuli im evident, anterolaterad setae $f$. Plate $\mathrm{H}$ not evident, setae $h 7$ (7-8). Distances between setae: $v_{1}-v_{1} 35$ (34-37), $v_{2}-v_{2} 42$ (41-44), $v_{1}-v_{2}$ 13 (13-14), $s c_{1}-s c_{1} 61$ (57-60), $v_{1}-s c_{1} 18$ (18-19), $s c_{2}-s c_{2}$ 62 (58-61), sc $c_{1}-s c_{2} 39$ (38-40), $c_{1}-c_{1} 61$ (57-64), $c_{1}-c_{2} 48$ (42-46), $d-d 59$ (57-58), f-f 37 (33-36).

Idiosomal venter (Fig. 10b). All coxal plates smooth; all coxal setae pointed; ap1-2 and appr well developed, ap2 reaching to appr; apsej absent; coxisternal field I with setae $1 a 3$ (2-2); alveoli of vestigial setae $1 b$ not evident; coxisternal field II with $2 a 2$ (2-2); alveoli of vestigial setae $2 b$ evident; coxisternal field III with subequal setae $3 a 7$ (7-8) and $3 b$ 7 (8-8). Distances between setae: $1 a-1 a 19$ (20-22), $2 a-2 a$ 27 (25-26), 3a-3b 19 (24-26).

Legs (Figs. 10c-10e). Setal formula for legs I-III (femur-

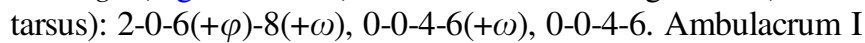
with a well-developed sickle-shaped claw, ambulacrum II-III each with a pair of well-developed claws. Leg I (Fig. 10c): femur, $d 3$ (2-2), slightly thickened, seta $l^{\prime} 16(15-16)$ thick and bluntended; tibia with $\varphi 5$ (5-5) baculiform, $d 28$ (29-31), $l^{\prime} 4$ (4-5), $l^{\prime \prime} 3$ (3-3), $v^{\prime} 5$ (5-6) stiff, $v^{\prime \prime} 9$ (8-9), seta $k 5$ (5-6); tarsus I, $\omega 3$ (3-4) digitiform, eupathidial setae $t c^{\prime} 9(8-9)$ and $t c^{\prime \prime} 10$ (9-10) distinctly blunt-ended, $p l^{\prime} 9$ (8-9), setae $u^{\prime \prime} 2$ (2-3), $p v^{\prime} 3$ (2-2) and $p v^{\prime \prime} 2(2-2)$ subequal, seta $s$ (5-5) spine-like, with a blunt tip, $p^{\prime} 1$ (1-2). Leg II. (Fig. 10d): tibia, $d 8$ (7-8), $l^{\prime} 7$ (6-7), $v^{\prime} 11$ $(10-11), v^{\prime \prime} 6$ (6-6); tarsus, $\omega 4$ (3-4) digitiform, $t c^{\prime} 7$ (6-7), setae $u^{\prime} 6$ (6-6) and $t c^{\prime \prime} 5$ (5-6) spine-like, $p l^{\prime \prime} 17$ (17-18), $p v^{\prime \prime} 3$ (3-3), $u^{\prime \prime} 2$ (2-2). Leg III (Fig. 10e): tibia, setae $d 7$ (7-8), $l^{\prime} 6(6-7), v^{\prime} 11(10-12), v^{\prime \prime} 6(5-6)$; tarsus, $t c^{\prime} 10(10-10)$, setae $u^{\prime}$ 6 (6-7) and $t c^{\prime \prime} 6$ (5-6) spine-like, $p l^{\prime \prime} 16$ (15-16), $p v^{\prime \prime} 3$ (3-3), $u^{\prime \prime} 2$ (2-2). 
Table 2. Comparison of selected characters (range of measurements if available) of all the described species of the leytei species group in the genus Eutarsopolipus (male is unknown for $E$. leytei); species abbreviated as E. pulcher n. sp. (Ep), E. leytei $(E l)$, E. dastychi $(E d)$, E. orpheus (Eo), E. biuncatus (Eb), and E. janus (Ej).

\begin{tabular}{|c|c|c|c|c|c|c|c|c|c|c|c|c|c|c|c|c|c|}
\hline \multirow{2}{*}{$\begin{array}{l}\text { Life stage } \\
\text { Character }\end{array}$} & \multicolumn{6}{|c|}{ Female } & \multicolumn{5}{|c|}{ Male } & \multicolumn{6}{|c|}{ Larval female } \\
\hline & $E p$ & $E l$ & $E d$ & Eo & $E b$ & $E j$ & $E p$ & $E d$ & Eo & $E b$ & $E j$ & $E p$ & $E l$ & $E d$ & Eo & $E b$ & $E j$ \\
\hline Gn. L. & $42-50$ & 78 & $47-50$ & $50-57$ & $44-46$ & $52-57$ & $25-36$ & $30-33$ & $30-32$ & $28-31$ & $28-37$ & $29-32$ & 56 & $37-40$ & $32-38$ & $30-34$ & $31-34$ \\
\hline Ch. S. L. & $44-51$ & 68 & $47-48$ & $23-28$ & $35-38$ & $45-51$ & $17-19$ & $23-26$ & 15 & $17-18$ & $25-28$ & $28-34$ & 54 & $35-40$ & $21-27$ & $25-27$ & $36-42$ \\
\hline Setae $c h$ & $18-25$ & 20 & $27-30$ & $10-18$ & $14-22$ & $25-35$ & $8-12$ & $12-15$ & $\mathrm{~m}$ & $1-2$ & $3-4$ & $20-25$ & 20 & $30-36$ & $31-35$ & $19-23$ & $26-33$ \\
\hline Setae $s u$ & $12-14$ & 3 & 22 & $11-15$ & $8-12$ & $15-20$ & $9-10$ & $9-10$ & $6-7$ & $4-6$ & $8-9$ & $10-12$ & 3 & $15-18$ & $6-7$ & $8-10$ & $12-15$ \\
\hline Setae $v_{1}$ & $11-14$ & 5 & $36-45$ & $17-26$ & $8-10$ & $19-24$ & $\mathrm{~m}$ & $5-10$ & $\mathrm{~m}$ & $m-2$ & $4-9$ & $11-13$ & $\mathrm{~m}$ & $42-50$ & $26-32$ & $12-14$ & $15-18$ \\
\hline Setae $s c_{1}$ & $9-13$ & 11 & 25 & $17-29$ & $7-9$ & $9-11$ & $\mathrm{~m}$ & $5-13$ & $\mathrm{~m}$ & $\mathrm{~m}$ & $\mathrm{~m}-2$ & $10-12$ & 10 & $25-28$ & $28-33$ & $5-6$ & $8-10$ \\
\hline Setae $s c_{2}$ & $51-60$ & 62 & $58-70$ & $47-59$ & $15-20$ & $36-40$ & $34-46$ & $60-70$ & $38-40$ & $2-3$ & $27-34$ & $62-72$ & 78 & 94-101 & $90-95$ & $51-52$ & $70-80$ \\
\hline Setae $c_{1}$ & $4-6$ & 12 & $18-19$ & $8-10$ & $5-7$ & $8-9$ & $\mathrm{~m}$ & 10 & $\mathrm{~m}$ & $\mathrm{~m}$ & $2-3$ & $7-8$ & 10 & $18-22$ & $14-18$ & $5-6$ & $7-10$ \\
\hline Setae $c_{2}$ & $4-6$ & 9 & $17-21$ & $9-18$ & $4-6$ & $8-10$ & $\mathrm{~m}$ & $5-7$ & $\mathrm{~m}$ & $\mathrm{~m}$ & 2 & $5-7$ & 9 & $17-21$ & $10-15$ & $3-4$ & $7-10$ \\
\hline Setae $d$ & $4-5$ & 12 & $18-21$ & $11-18$ & $4-5$ & $9-10$ & $\mathrm{~m}$ & $8-10$ & $\mathrm{~m}$ & $\mathrm{~m}$ & $\mathrm{~m}-2$ & $6-7$ & 9 & $20-23$ & $15-17$ & $4-5$ & $7-9$ \\
\hline Setae $f$ & 5 & 8 & 22 & $10-11$ & $4-5$ & $7-9$ & $\mathrm{~m}$ & $3-4$ & $\mathrm{~m}$ & $\mathrm{~m}$ & $\mathrm{~m}-2$ & $7-9$ & 8 & $16-18$ & $8-12$ & $4-5$ & $6-8$ \\
\hline Setae $h_{1}$ & - & - & - & - & - & - & $\mathrm{m}$ & $\mathrm{m}$ & $\mathrm{m}$ & $\mathrm{m}$ & $\mathrm{m}$ & $64-67$ & 148 & $65-90$ & $55-64$ & $65-70$ & 100 \\
\hline Setae $h_{2}$ & - & - & - & - & - & - & - & - & - & - & - & $1-2$ & 67 & $\mathrm{~m}$ & $\mathrm{~m}$ & $3-4$ & $4-6$ \\
\hline Setae $1 a$ & $5-6$ & $\sim 4$ & $5-6$ & $4-5$ & $5-6$ & $6-7$ & $\mathrm{~m}$ & $2-5$ & $\mathrm{~m}$ & $2-3$ & $4-5$ & $5-7$ & $\sim 2$ & $8-10$ & $6-8$ & $2-3$ & $4-5$ \\
\hline Setae $2 a$ & $5-7$ & $\sim 4$ & 5 & $3-4$ & $4-5$ & $6-7$ & $\mathrm{~m}$ & $3-4$ & $\mathrm{~m}$ & $2-3$ & $4-5$ & $4-6$ & $\sim 2$ & $7-10$ & $8-9$ & $3-4$ & $4-5$ \\
\hline Setae $3 a$ & $4-5$ & 8 & 9 & $2-3$ & $5-6$ & $6-9$ & $\mathrm{~m}$ & $\sim 2$ & $\mathrm{~m}$ & 3 & $5-6$ & $5-6$ & 4 & $10-13$ & $9-11$ & $4-5$ & $7-8$ \\
\hline Setae $3 b$ & $5-6$ & 4 & 7 & 3 & $4-5$ & $6-7$ & $\mathrm{~m}$ & $\sim 4$ & $\mathrm{~m}$ & $2-3$ & $5-6$ & 5 & 2 & $10-12$ & $9-10$ & $3-4$ & $5-6$ \\
\hline Sol. Ta I $\omega$ & $4-5$ & $\sim 2$ & $4-5$ & $5-6$ & $3-4$ & $4-5$ & $4-5$ & $5-7$ & 4 & 3 & $3-4$ & $4-5$ & $\sim 2$ & $4-5$ & $4-5$ & $3-4$ & $4-5$ \\
\hline Sol. Ti I $\varphi$ & $7-9$ & 7 & 10 & $7-8$ & $6-7$ & $6-8$ & $6-8$ & $5-6$ & $5-6$ & $4-5$ & $6-7$ & $7-8$ & 7 & $7-9$ & $8-9$ & $6-7$ & $7-8$ \\
\hline
\end{tabular}




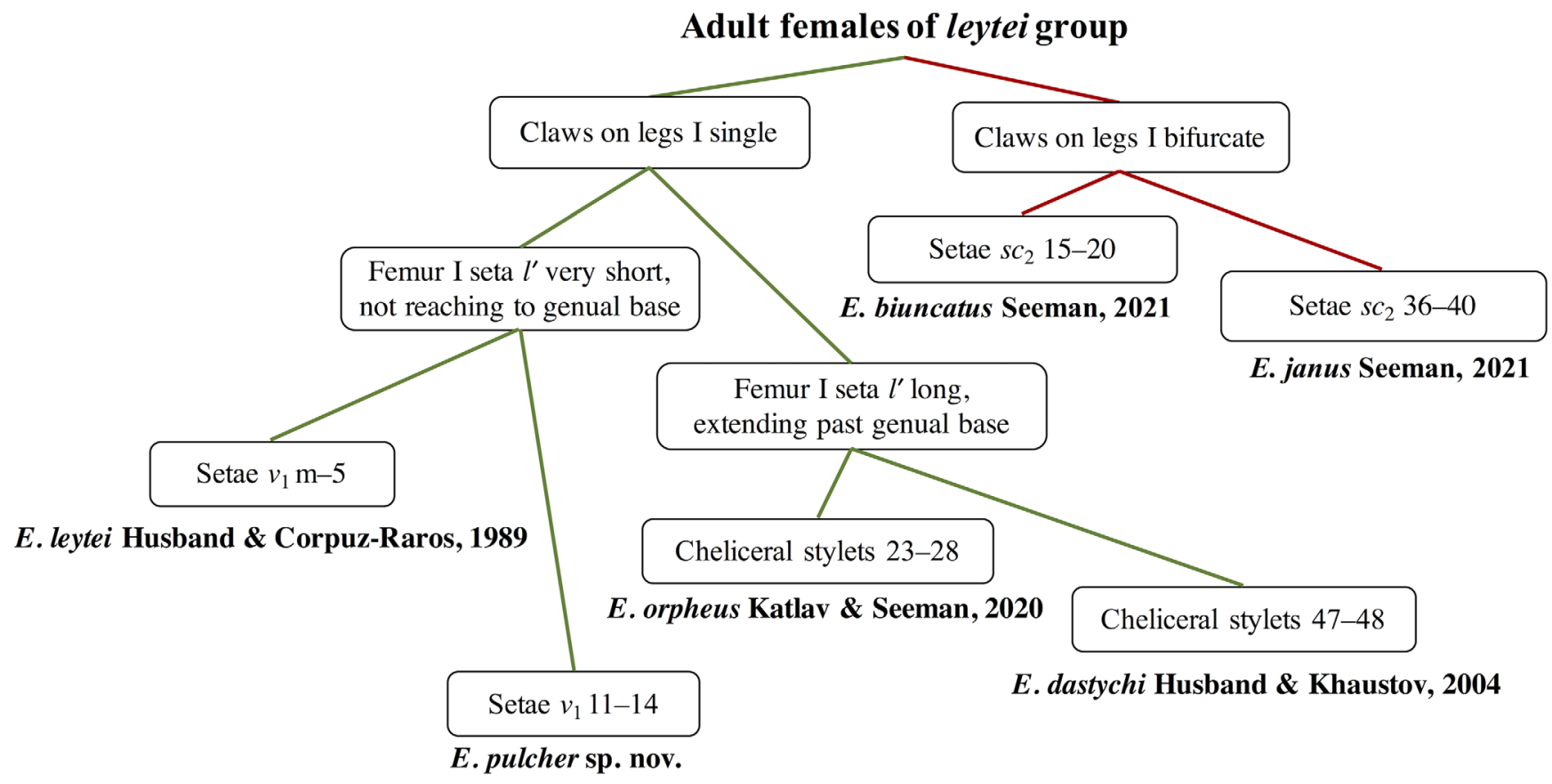

Figure 9. Key to the world species of Eutarsopolipus in the leytei group (based on adult females).

\section{Male (Unknown)}

\section{Larval female (Fig. 11) $(n=5)$}

Gnathosoma (Figures 11a-11b). Length 39-46, width 38-40; cheliceral stylets length 29-32; pharynx length 13-15, pharynx width 10-11; ch 17-19 pointed; su 3-4 needle-like; distance between setae $c h-c h$ 22-26, su-su 12-14.

Idiosoma (Figs. 11a-11b). Length 165-195, width 125-145.

Idiosomal dorsum (Fig. 11a). All dorsal setae needle-like except $s c_{2}$ attenuate; $\operatorname{PrS}$ with setae $v_{1} 6-7, v_{2}$ vestigial, $s c_{1}$ 6-7, $s c_{2}$ 95-98. Plate C setae $c_{1}$ 5-6, $c_{2}$ 5-6. Plate D setae $d$ 6-7; cupuli ia anterolaterad setae $d$. Plate EF setae $f$ 7-8; cupuli im anterolaterad setae $f$. Plate $\mathrm{H}$ situated ventrally with setae $h_{1}$ 97-101 and $h_{2}$ 22-24. Distances between setae: $v_{1}-v_{1}$ 24-26, $v_{2}-v_{2} \quad 44-47, v_{1}-v_{2} \quad 12-14, s c_{1}-s c_{1}$ 59-62, $v_{1}-s c_{1}$ 20-22, $s c_{2}-s c_{2} 57-58, s c_{1}-s c_{2} 40-42, c_{1}-c_{1} 83-86, c_{1}-c_{2} 21-23, d-d$ 34-36, $f-f 28-29$.

Idiosomal venter (Fig. 11b). All coxal plates smooth; all coxal setae tiny and pointed; ap1-2 and apsej evident; coxisternal fields I-II each divided from its pair, with setae $1 a$ 1-1; alveoli of setae $1 b$ not evident; coxisternal field II with $2 a$ 2-3; alveoli of setae $2 b$ not evident; coxisternal field III widened, with setae $3 a 7-9$ and $3 b 7-8$ subequal. Distances between setae: $1 a-1 a$ 22-34, 2a-2a 28-30, 3a-3b 21-22.

Legs (Figs. 11c-11e). Setal formula for legs I-III (femur-

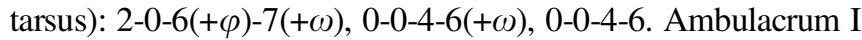
with a small bifid claw, ambulacrum II-III each with a pair of tiny claws. Leg I (Fig. 11c): femur, $d$ microseta, seta $l^{\prime} 4-5$ stiff; tibia, $\varphi$ 3-4 baculiform, $d$ 17-21, seta $l^{\prime} 4-5$ slightly thickened, $l^{\prime \prime} 2-3, v^{\prime} 3-4$, seta $v^{\prime \prime} 4-5$ slightly thickened and blunt-ended, seta $k$ 2-3; tarsus, $\omega 3-4$ digitiform, eupathidial setae $t c^{\prime} 7-8$ and $t c^{\prime \prime}$ 7-8 subequal, distinctly blunt-ended, $p l^{\prime}$ 6-6, setae $p v^{\prime} 1-2, p v^{\prime \prime} 2-3$, seta $s$ 4-5 blunt spur-like, $p^{\prime} 1-1 ; u^{\prime \prime}$ not visible. Leg II. (Fig. 11d): tibia, $d$ 4-5, $l^{\prime}$ 6-7, $v^{\prime}$ 6-7, $v^{\prime \prime}$ 4-6; tarsus, $\omega$ 2-3 digitiform, $t c^{\prime} 5-7$, setae $u^{\prime} 4-5$ and $t c^{\prime \prime} 5-6$ blunt spur-like, $p l^{\prime \prime} 10-12, p v^{\prime \prime} 2-2, u^{\prime \prime} 2-2$. Leg III (Fig. 11e): tibia, $d$ 5-6, $l^{\prime}$ 6-7, $v^{\prime}$ 6-8, $v^{\prime \prime} 3-5$; tarsus, $t c^{\prime}$ 6-7, setae $u^{\prime}$ 5-6 and $t c^{\prime \prime}$ 6-7 blunt spur-like, $p l^{\prime \prime} 10-13, p v^{\prime \prime} 3-4, u^{\prime \prime} 1-1$.

\section{Differential diagnosis}

The new species belongs to a subgroup of the myzus species group that shares a combination of the following characters in adult females: ambulacrum I claw well-developed, idiosoma without lateral bulges or posteriorly without wrinkled lobes, shield C not divided, femur I seta $l^{\prime}$ developed (not microseta), and cheliceral stylets less than $35 \mu \mathrm{m}$ long [13]. This assemblage includes $E$. chlaenii n. sp. and four other species: E. steveni Khaustov, 2010, E. anichtchenkoi, Hajiqanbar \& Mortazavi, 2012, E. gombrooni Hajiqanbar \& Mortazavi, 2019, and E. oconnori Hajiqanbar \& Mortazavi, 2019. Among these species, E. chlaenii n. sp. is more similar to E. anichtchenkoi and $E$. oconnori by having setae $h$ and $f$ subequal. However, it is readily distinguishable from $E$. anichtchenkoi by having developed setae $v_{1}, s c_{1}, 1 a$ and $2 a$ (adult female with microsetae $v_{1}$, $s c_{1}, 1 a$ and $2 a$ in E. anichtchenkoi), $s c_{2}$ almost five times longer than $h_{1}$ (adult female with $s c_{2}$ at least nine times longer than $h_{1}$ in E. anichtchenkoi) and tarsus III with six setae (tarsus III with seven setae in E. anichtchenkoi). Eutarsopolipus chlaenii n. sp. also differs from $E$. oconnori by having shorter distances $c_{1}-c_{1}$, $d-d, f-f$ in the adult female $(64,59,37$ vs. $101,113,86$, respectively, in E. oconnori) and longer setae $s u$ and $h_{1}$ and cheliceral stylets in larval females $(101,4,32$, vs. 61, m, 26, respectively, 


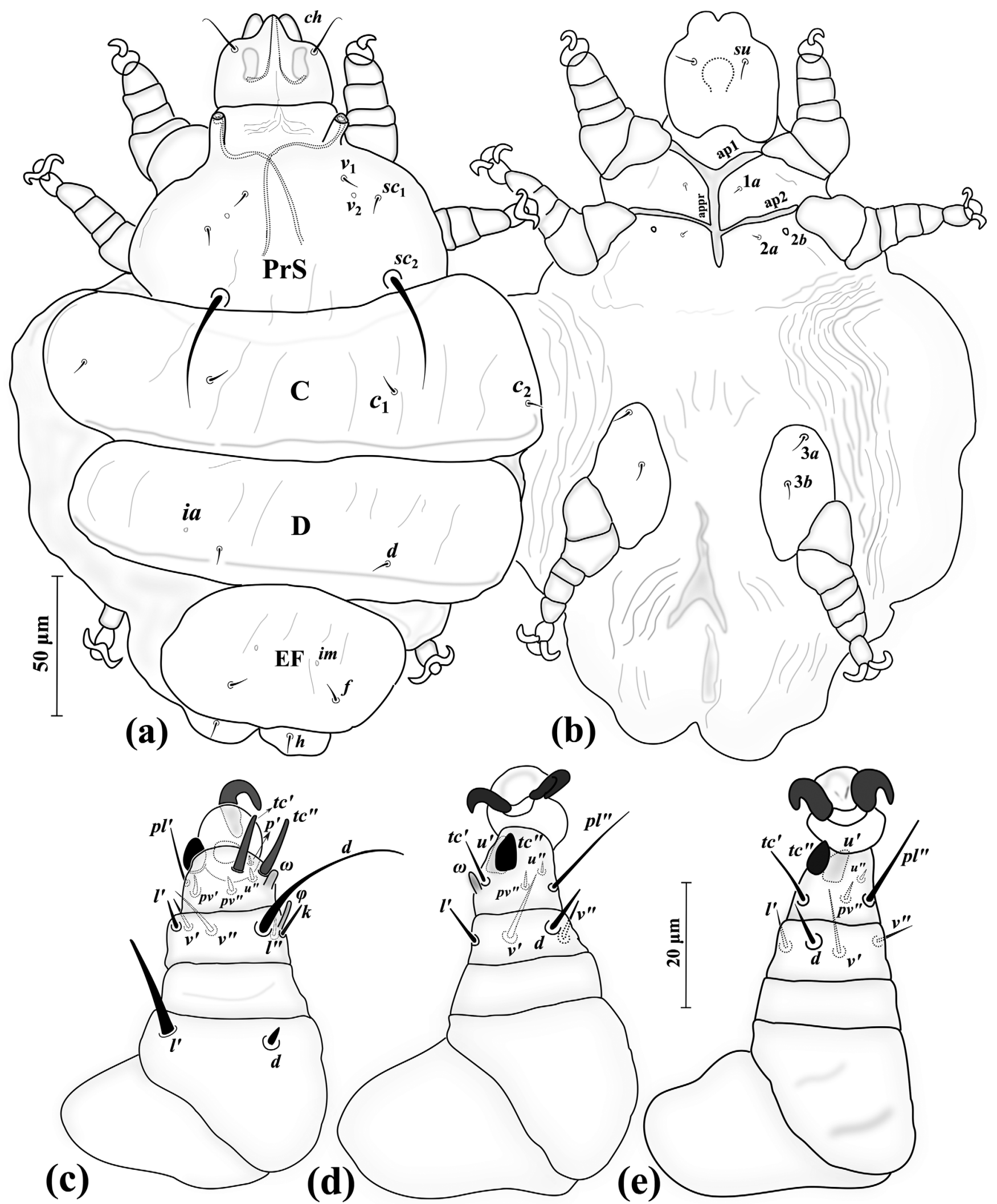

Figure 10. Eutarsopolipus chlaenii n. sp. (adult female). (a) Body dorsum; (b) body venter; (c) right leg I; (d) ventral view of tarsus I; (e) right leg II; (f) right leg III. All legs in dorsal view. 


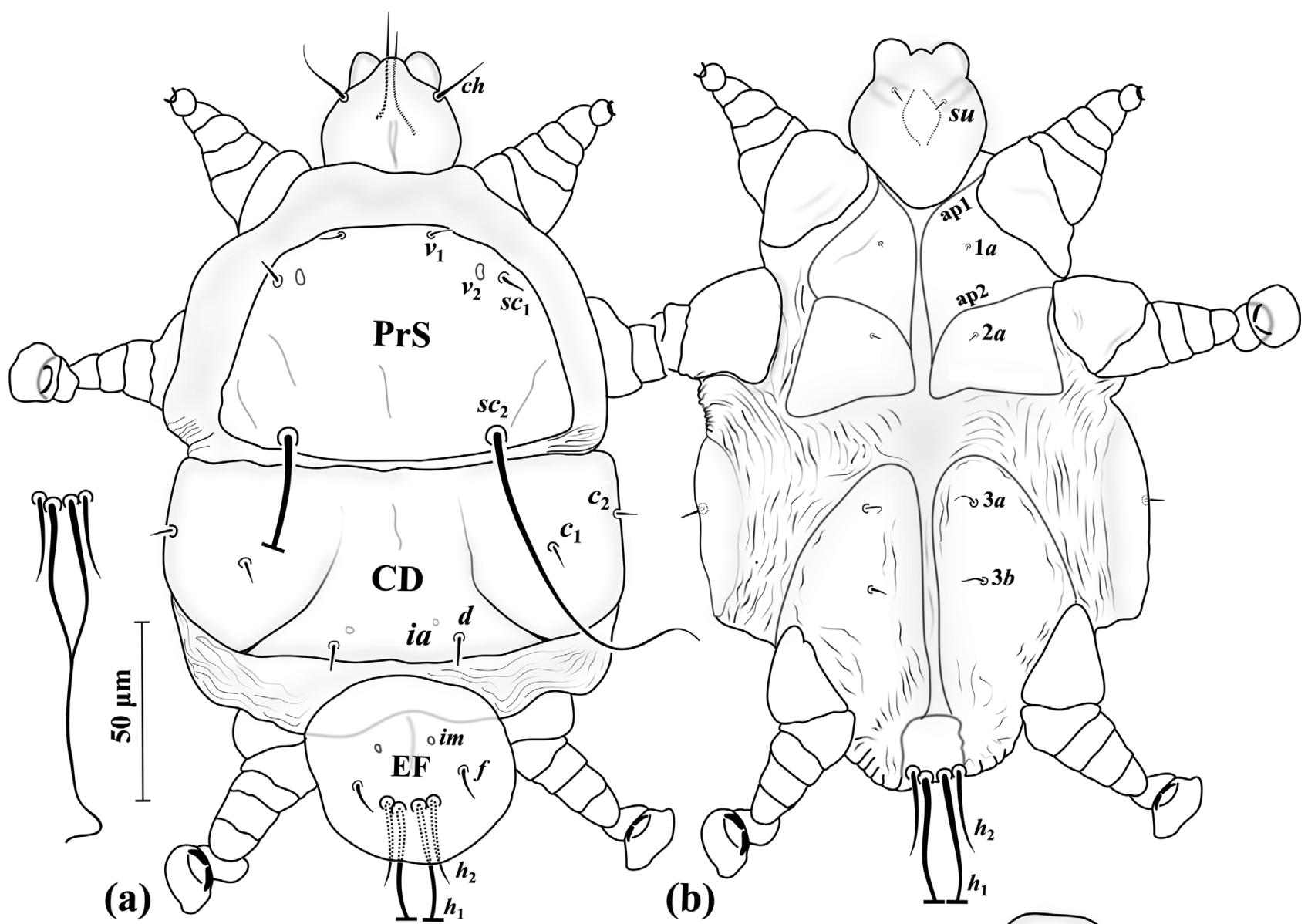

(a)

(b)

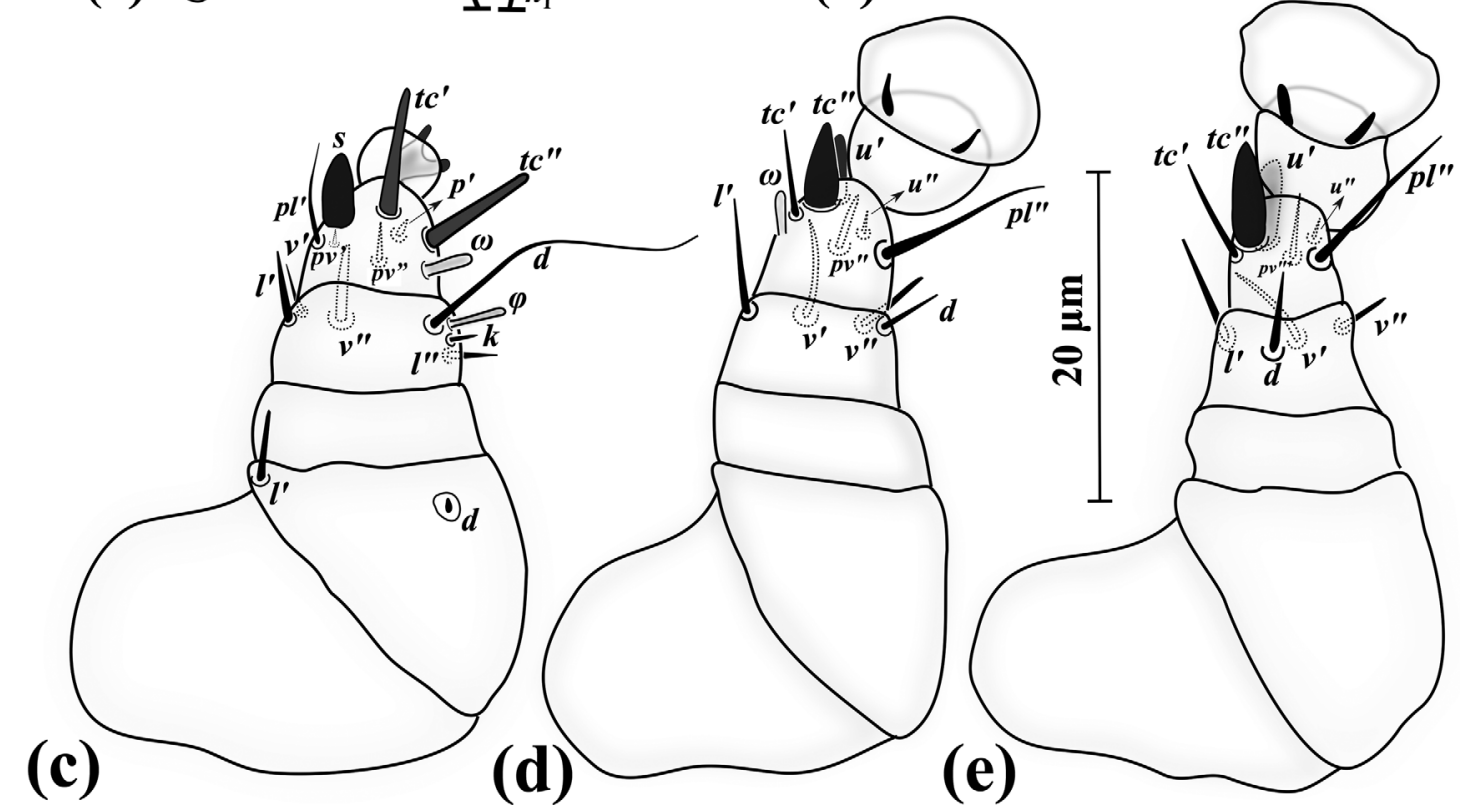

Figure 11. Eutarsopolipus chlaenii n. sp. (larval female). (a) Body dorsum; (b) body venter; (c) right leg I; (d) right leg II; (e) right leg III. All legs in dorsal view.

in E. oconnori). All the important characters among these five species of the myzus species group are compared for all life stages (excluding $E$. chlaenii n. sp. with unknown male) in Table 3. Among adult females of the myzus species group with a strong claw on ambulacrum I, lateral bulges or posterior wrinkled lobes and entire shield $\mathrm{C}$, six species have short cheliceral stylets (less than $35 \mu \mathrm{m}$ long). The key to this subgroup is presented in Figure 12. 
Table 3. Comparison of selected characters (range of measurements if available) of five closely related species of the myzus species group in Eutarsopolipus (male is unknown for E. chlaenii n. sp.): E. chlaenii n. sp. (Ec), E. steveni (Es), E. anichtchenkoi (Ea), E. gombrooni (Eg), and E. oconnori $(E a)$.

\begin{tabular}{|c|c|c|c|c|c|c|c|c|c|c|c|c|c|c|}
\hline \multirow{2}{*}{$\begin{array}{l}\text { Life stage } \\
\text { Character }\end{array}$} & \multicolumn{5}{|c|}{ Female } & \multicolumn{4}{|c|}{ Male } & \multicolumn{5}{|c|}{ Larval female } \\
\hline & Ec & Es & $E a$ & $E g$ & Eo & Es & $E a$ & $E g$ & Eo & $E c$ & Es & $E a$ & $E g$ & Eo \\
\hline Gn. L. & $43-45$ & $31-34$ & $47-50$ & $43-50$ & 50 & $21-22$ & $26-29$ & $24-26$ & 25 & $39-46$ & $22-24$ & $30-35$ & 23 & $26-36$ \\
\hline Ch. S. L. & $28-30$ & $28-31$ & $30-35$ & $29-32$ & 34 & $14-15$ & $12-13$ & $13-16$ & 13 & $29-32$ & $19-20$ & $17-19$ & 18 & $16-26$ \\
\hline Setae $c h$ & $15-16$ & $17-19$ & $12-13$ & $14-16$ & 14 & $6-7$ & $8-10$ & 4 & 5 & $17-19$ & $15-17$ & $12-13$ & 14 & $11-14$ \\
\hline Setae $s u$ & $5-6$ & $6-7$ & $4-6$ & $5-7$ & 5 & $3-4$ & $2-3$ & 2 & $\mathrm{~m}$ & $3-4$ & $7-8$ & 2 & 7 & $\mathrm{~m}$ \\
\hline Setae $v_{1}$ & $5-6$ & $5-6$ & $\mathrm{~m}$ & $6-7$ & 8 & $3-4$ & $\mathrm{~m}$ & $3-4$ & $\mathrm{~m}$ & $6-7$ & $3-4$ & $6-7$ & 5 & $5-7$ \\
\hline Setae $s c_{1}$ & $5-6$ & $5-6$ & $\mathrm{~m}$ & 8 & 8 & $3-4$ & $\mathrm{~m}$ & $3-4$ & $\mathrm{~m}$ & $6-7$ & $3-4$ & $5-6$ & 5 & $7-8$ \\
\hline Setae $s c_{2}$ & $38-42$ & $26-28$ & $37-45$ & $18-21$ & 45 & $35-37$ & $39-45$ & $26-31$ & 17 & $95-98$ & $41-47$ & $78-79$ & 43 & $85-93$ \\
\hline Setae $c_{1}$ & $6-7$ & $6-8$ & $4-5$ & $5-9$ & 9 & $4-5$ & $\mathrm{~m}$ & $\mathrm{~m}-3$ & $\mathrm{~m}$ & $5-6$ & $4-5$ & 7-9 & 5 & $6-7$ \\
\hline Setae $c_{2}$ & $5-6$ & $6-7$ & $4-5$ & $7-8$ & 9 & $4-5$ & $\mathrm{~m}$ & $4-5$ & $\mathrm{~m}$ & $5-6$ & $4-5$ & 6 & 4 & $6-7$ \\
\hline Setae $d$ & $5-6$ & $6-7$ & $4-5$ & $6-7$ & 8 & $4-5$ & $\mathrm{~m}$ & $\mathrm{~m}-4$ & $\mathrm{~m}$ & $6-7$ & $4-5$ & 9 & 3 & 7 \\
\hline Setae $f$ & $6-7$ & $7-8$ & $4-5$ & $7-8$ & 8 & $4-4$ & $\mathrm{~m}$ & $\mathrm{~m}-3$ & $\mathrm{~m}$ & 7-8 & $6-7$ & 9 & 6 & 5-8 \\
\hline Setae $h_{1}$ & $7-8$ & $24-26$ & $3-4$ & $13-16$ & 9 & - & - & - & - & 97-101 & $70-75$ & $140-172$ & 89 & $57-61$ \\
\hline Setae $h_{2}$ & - & - & - & - & - & - & - & - & - & $22-24$ & $24-27$ & 20-21 & 20 & $12-20$ \\
\hline Setae $1 a$ & $2-3$ & $2-3$ & $\mathrm{~m}$ & $2-3$ & $\mathrm{~m}$ & $\mathrm{v}$ & $\mathrm{m}$ & $\mathrm{m}$ & $\mathrm{m}$ & 1 & 2 & $\mathrm{~m}$ & $\mathrm{~m}$ & $\mathrm{~m}$ \\
\hline Setae $2 a$ & 2 & $3-4$ & $\mathrm{~m}$ & $3-4$ & $\mathrm{~m}$ & 2 & $\mathrm{~m}$ & $1-2$ & $\mathrm{~m}$ & $2-3$ & 3 & $\mathrm{~m}$ & 2 & $\mathrm{~m}$ \\
\hline Setae $3 a$ & $7-8$ & $\sim 8$ & $4-5$ & $8-9$ & 9 & $3-4$ & $\mathrm{~m}$ & $3-4$ & $\mathrm{~m}$ & $7-9$ & 10 & 3 & 10 & $5-9$ \\
\hline Setae $3 b$ & $7-8$ & $8-9$ & $4-5$ & 8 & 11 & 4 & $\mathrm{~m}$ & $4-5$ & $\mathrm{~m}$ & $7-8$ & 6 & 4 & 9 & $6-8$ \\
\hline Gen. cap. L. & - & - & - & - & - & $21-22$ & $26-29$ & $31-34$ & 18 & - & - & - & - & - \\
\hline Gen. cap. W. & - & - & - & - & - & $21-22$ & $25-28$ & $34-35$ & 24 & - & - & - & - & - \\
\hline Sol. Ta I $\omega$ & $3-4$ & $3-4$ & 2 & 3 & 3 & $3-4$ & 3 & $3-4$ & 6 & $3-4$ & $3-4$ & $2-3$ & $\sim 2$ & $2-3$ \\
\hline Sol. Ti I $\varphi$ & 5 & $4-5$ & 5 & $4-5$ & 5 & $4-5$ & 4 & $3-5$ & 8 & $3-4$ & $4-5$ & 4 & 4 & $4-5$ \\
\hline Sol. Ta II $\omega$ & $3-4$ & $3-4$ & 2 & 3 & 3 & $3-4$ & 2 & $3-4$ & 6 & $2-3$ & $3-4$ & 3 & 3 & $3-4$ \\
\hline Fe I seta $d$ & $2-3$ & $\mathrm{~m}$ & $\mathrm{~m}$ & $\mathrm{~m}$ & $\sim 1$ & $\mathrm{~m}$ & $\mathrm{~m}$ & $\mathrm{~m}$ & $\mathrm{~m}$ & $\mathrm{~m}$ & $\mathrm{~m}$ & $\mathrm{~m}$ & $\mathrm{~m}$ & $\mathrm{~m}$ \\
\hline Fe I seta $l$ ' & $15-16$ & $\sim 14$ & $12-13$ & $11-13$ & 13 & $\mathrm{~m}$ & $\sim 1$ & $\sim 1$ & 4 & $4-5$ & $\mathrm{~m}$ & $\sim 3$ & 2 & $4-5$ \\
\hline$\underline{\text { Ti I seta } d}$ & $28-31$ & $\sim 20$ & $\sim 22$ & $17-26$ & 18 & $\sim 17$ & $\sim 22$ & $15-16$ & 28 & $17-21$ & $\sim 18$ & $\sim 18$ & $\sim 20$ & $\sim 19$ \\
\hline
\end{tabular}

\section{Adult females of six closely related species of myzus group}

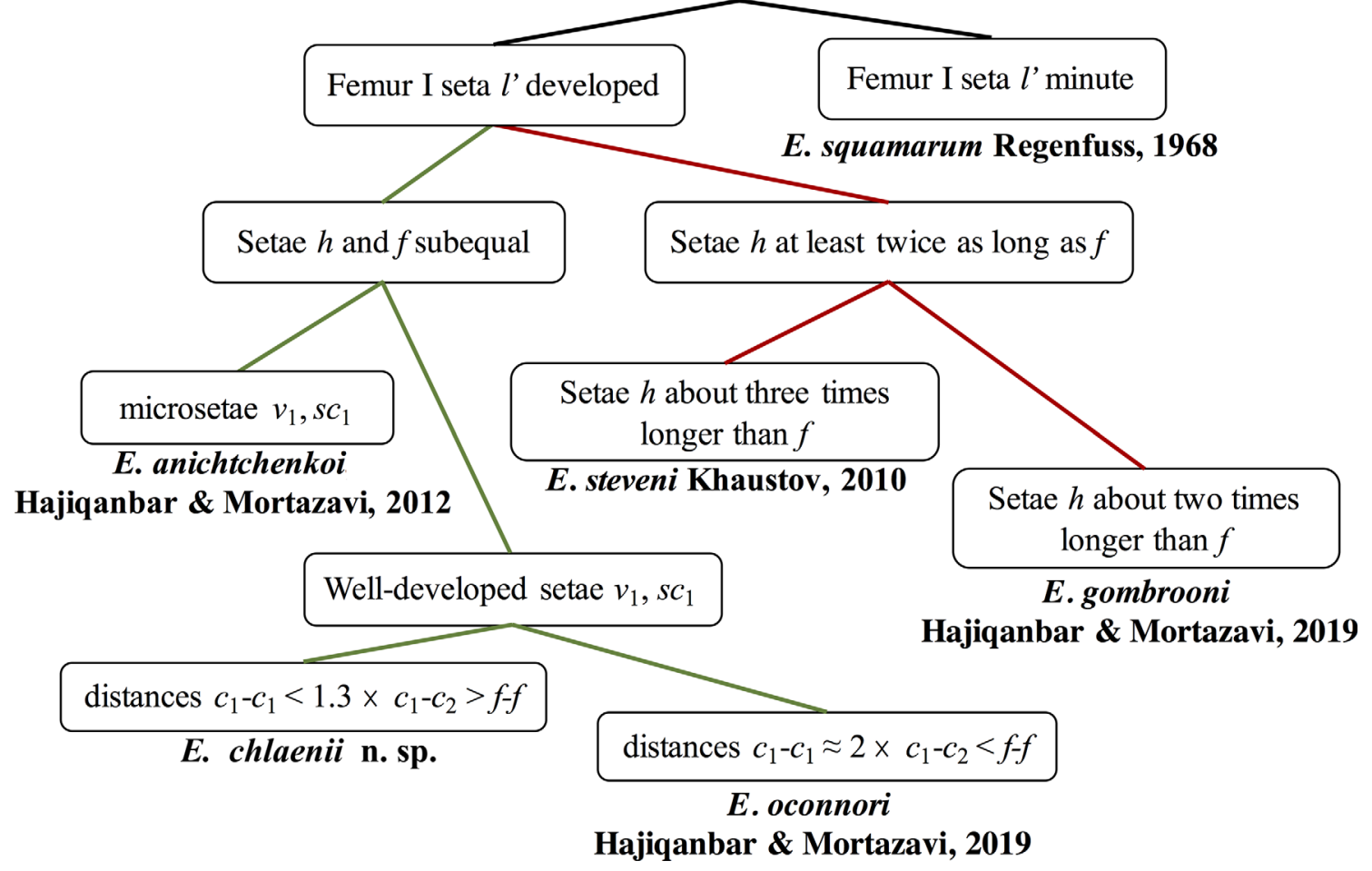

Figure 12. Key to closely related species of myzus group (based on adult females) possessing similar characters including short cheliceral stylets $(<35 \mu \mathrm{m}$ long). 


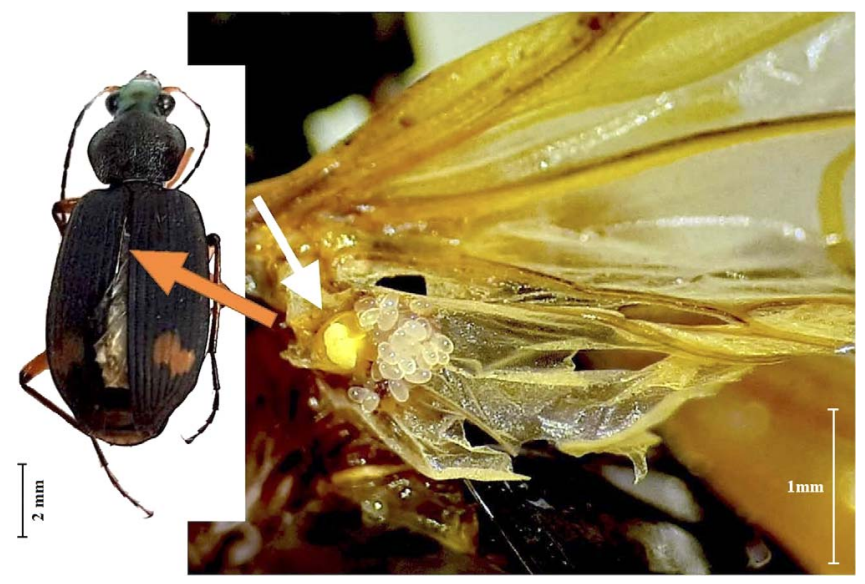

Figure 13. Eutarsopolipus chlaenii n. sp. under the elytra of the host beetle Chlaenius flaviguttatus Macleay, 1825, localized on the proximal portion of the host's hindwing, with view of the mite's engorged female (yellow colour) producing eggs (milky colour).

\section{Discussion}

Among all Eutarsopolipus, leytei is apparently the most primitive group that represents the putative plesiomorphies of a well-developed tracheal system as well as retention of genual I-III setae (2-1-1) and all femoral I setae (3 setae). Conversely, the pterostichi group with a missing tracheal system and genual I-III setae (0-0-0), reduction of femoral I setation ( 2 setae) and sometimes reduction/absence of ambulacral claws [as in E. echinatus, 43] may be relatively more derivative than the other Australian Eutarsopolipus [31, 43]. However, the myzus group, possessing a combination of plesiomorphies (well-developed tracheal system and ambulacral claws) and some apomorphies [reduction of femoral I setation (2 setae) and absence of genual I-III setae (0-0-0)], may hold an intermediate position. It is surprising that in our study such considerable species diversity was detected in a single location following a minimal sampling effort preformed across fewer than three weeks. This may substantiate the previously held notion that Australia exhibits diverse Eutarsopolipus fauna with a wide gradient of morphological variations [42]. Despite a few sporadic studies on Australian Eutarsopolipus, six out of the ten known species groups that exist across the world (including ochoai, megacheli and secundus) have so far been recorded from Australia ([31, 42, 44], present study). However, the rich diversity of Australian carabid beetles may posit the idea that the current knowledge about their associated Eutarsopolipus mites is still in its infancy; therefore, more extensive faunistic studies in different regions could potentially lead to the discovery of enormous diversity in Eutarsopolipus.

With the description of E. chlaenii, this study reports the myzus group for the first time in Australia, thereby extending its distribution to Oceania, and beyond the previously recorded Holarctic, Afrotropical and Oriental realms [12, 22]. About half of the species of this group (13/25) are parasites of carabids of the genus Chlaenius Bonelli $[12,22]$. Furthermore, the finding of E. pulcher n. sp. from G. pulcher is the second record of the leytei group from a native carabid of the genus Gnathaphanus Macleay, 1825 (tribe Harpalini). Recently, a study in the same location found another species, E. orpheus from under the elytra of Gnathaphanus melbournensis (Castelnau, 1867), probably suggesting more specific association of the leytei group with carabids of Gnathaphanus. This carabid genus is apparently native to the Australasian and Oriental regions and represents more than 15 species in Australia [4] with G. pulcher and G. melbournensis being highly abundant in eastern Australia [3]. It is interesting, however, that the only Palearctic representative of the leytei group, E. dastychi, was found from Calathus of the carabid tribe Sphodrini [20] which is phylogenetically diverged from the carabid tribe Harpalini. This kind of counterintuitive host range is even more profound among the myzus and pterostichi groups, both of which are associated with carabids of the two distantly related subfamilies, Harpalinae and Scaritinae [26, 42], suggesting that several episodes of host switching may have contributed to the evolution of their host associations.

Carabid beetles are generalist predators that feed on a variety of small invertebrates including important agricultural pests and thus serve as important biocontrol agents [34]. However, their ecological interactions are often hard to predict [9]. It is unknown how the parasitic role of Eutarsopolipus mites can shape the ecology and evolution of carabids, yet incorporation of such information may contribute to models predicting interaction networks of carabids for future biocontrol programs.

\section{Conflict of interest}

The authors declare that they do not have any conflict of interest.

Acknowledgements. We sincerely thank Geoff Monteith (former Senior Curator of Entomology at the Queensland Museum) for his assistance in identifying some of the host beetles. Special thanks to the first author's mother, Shams Paryav for her kind assistance in filed insect collection. AK was supported by a Western Sydney University Postgraduate Research Award. OS was partially funded by the Australian Biological Resources Study (grant RG18-02) and by the Queensland Museum.

\section{References}

1. Abbot P, Dill LM. 2001. Sexually transmitted parasites and sexual selection in the milkweed leaf beetle, Labidomera clivicollis. Oikos, 92, 91-100.

2. Athias-Binche F. 1993. From phoresy to parasitism: the example of mites and nematodes. Research and Reviews in Parasitology-Revista, 53, 73-79.

3. Atlas of Living Australia. 2020. https://bie.ala.org.au/species/ urn:1sid:biodiversity.org.au:afd.taxon:7bbbcf53-08e7-4c98-8373211849be892c; accessed 10 March 2020.

4. Australian Faunal Directory. 2020. https://biodiversity.org.au/ afd/taxa/Gnathaphanus; accessed 10 March 2020.

5. Baehr M, Will K. 2019. Carabidae Latreille, 1802, in "Australian Beetles": Archostemata, Myxophaga, Adephaga, Polyphaga, Vol. 2, Slipinskí A, Lawrence JF, Editors. CSIRO Publishing: Melbourne, Vic., Australia. p. 61-217.

6. Bartlow AW, Agosta SJ. 2021. Phoresy in animals: review and synthesis of a common but understudied mode of dispersal. Biological Reviews, 96, 223-246. 
7. Bochkov AV, OConnor BM, Wauthy G. 2008. Phylogenetic position of the mite family Myobiidae within the infraorder Eleutherengona (Acariformes) and origins of parasitism in eleutherengone mites. Zoologischer Anzeiger, 247, 15-45.

8. Cross EA, Moser JC. 1971. Taxonomy and biology of some Pyemotidae (Acarina: Tarsonemoidea) inhabiting bark beetle galleries in North American conifers. Acarologia, 13, 47-64.

9. De Heij SE, Willenborg CJ. 2020. Connected carabids: Network interactions and their impact on biocontrol by carabid beetles. BioScience, 70, 490-500.

10. Gullan PJ, Cranston PS. 2014. The insects: an outline of entomology, 3rd ed. John Wiley \& Sons.

11. Hajiqanbar H, Husband RW, Kamali K, Saboori A, Kamali H. 2007. Ovacarus longisetosus n. sp. (Acari: Podapolipidae) from Amara (Paracelia) saxicola Zimm. (Coleoptera: Carabidae) and new records of Coccipolipus, Dorsipes, Eutarsopolipus and Tarsopolipus from Iran. International Journal of Acarology, 33, 241-244.

12. Hajiqanbar H, Mortazavi A. 2012. First record of the myzus species group (Acari: Podapolipidae: Eutarsopolipus Berlese, 1911) from Asia, with the description of two new species parasitising carabid beetles. Systematic Parasitology, 83, 189-202.

13. Hajiqanbar H, Mortazavi A, Khaustov A. 2019. Two new species of Eutarsopolipus (Acari: Prostigmata: Podapolipidae) parasitizing Syntomus lateralis (Coleoptera: Carabidae) from Iran. Zootaxa, 4647, 154-167.

14. Halliday B. 2019. The enemy of my parasite is my friend: the possible role of predatory mites as biological control agents of pest beetles in soil. International Journal of Acarology, 45, 189-196.

15. Houck MA, OConnor BM. . 1991. Ecological and evolutionary significance of phoresy in the Astigmata. Annual Review of Entomology, 36, 611-636.

16. Hunter PE, Rosario RM. 1988. Associations of Mesostigmata with other arthropods. Annual Review of Entomology, 33, 393-417.

17. Hurst GD, Sharpe RG, Broomfield AH, Walker LE, Majerus TM, Zakharov IA, Majerus ME. 1995. Sexually transmitted disease in a promiscuous insect, Adalia bipunctata. Ecological Entomology, 20, 230-236.

18. Husband RW. 1984. Dilopolipus, Panesthipolipus, Peripolipus and Stenopolipus, new genera of Podapolipidae (Acarina) from the Indo-Australian Region. International Journal of Acarology, $10,251-269$

19. Husband RW. 2007. Regenpolipus hexastichus n. sp. (Acari: Podapolipidae), parasite of Anthia hexastichum Gerstaecker (Coleoptera: Carabidae), from Kenya. International Journal of Acarology, 33, 327-332.

20. Husband RW, Khaustov AA. 2004. A new species of Eutarsopolipus (Acari: Podapolipidae) from Calathus fuscipes (Coleoptera: Carabidae) from Ukraine. International Journal of Acarology, 30, 329-333.

21. Husband RW, Kurosa K. 2000. Two new genera and a new species of mites (Acari: Podapolipidae) associated with weevils (Coleoptera: Curculionidae) in Argentina. International Journal of Acarology, 26, 247-255.

22. Husband RW, Kurosa K. 2013. Eutarsopolipus asiaticus sp. nov. (Acari: Podapolipidae), subelytral parasite of Chlaenius costiger Chaudoir (Coleoptera: Carabidae) from Japan. Systematic \& Applied Acarology, 18, 61-70.

23. Husband RW, Raros LA. 1989. New species of Podapolipus and a new species of Eutarsopolipus (Acari: Podapolipidae) from the Philippines. Philippine Entomologist, 7, 525-536.

24. International Code of Zoological Nomenclature. 1999. The International Trust for Zoological Nomenclature (ed.), London.
25. Kaliszewski M, Athias-Binche F, Lindquist EE. 1995. Parasitism and parasitoidism in Tarsonemina (Acari: Heterostigmata) and evolutionary considerations. Advances in Parasitology, 35, 335-367.

26. Katlav A, Hajiqanbar H. 2018. First description of male and larval female of parasitic mite Eutarsopolipus abdominis (Acari: Podapolipidae) with redescription of the adult female. Journal of Parasitology, 104, 1-9.

27. Katlav A, Hajiqanbar H, Talebi AA. 2014. Dorsipes caspius n. sp. (Acari: Podapolipidae), a subelytral parasite of Pterostichus caspius (Menetries) (Coleoptera: Carabidae) with notes on host range of the genus and the distribution of the platysmae group. Systematic Parasitology, 89, 117-132.

28. Katlav A, Hajiqanbar H, Talebi AA. 2014. First record of the genus Acanthomastix Mahunka, 1972 (Acari: Dolichocybidae) from Asia, with the description of a new species. International Journal of Acarology, 40, 7-14.

29. Katlav A, Hajiqanbar H, Talebi AA. 2015. First record of the genus Aethiophenax (Acari: Acarophenacidae) from Asia, redefinition of the genus and description of a new species. Journal of Asia Pacific Entomology, 18, 389-395.

30. Katlav A, Hajiqanbar H, Talebi AA. 2015. Pseudopygmephorellus mazandaranicus sp. nov. (Acari: Heterostigmata: Pygmephoridae), phoretic on scarabaeid dung beetles (Coleoptera: Scarabaeidae) from Iran. Zootaxa, 3919, 100-110.

31. Katlav A, Riegler M, Seeman OD. 2020. Tiny hitchhikers and parasites: a review of Australian heterostigmatic mites (Acari: Prostigmata) associated with insects, with description of three new species. Austral Entomology, 59, 401-421.

32. Lindquist EE. 1986. The world genera of Tarsonemidae (Acari: Heterostigmata): a morphological, phylogenetic, and systematic revision, with a reclassification of family-group taxa in the Heterostigmata. Memoirs of the Entomological Society of Canada, 118, 1-517.

33. Linz DM, Hu AW, Sitvarin MI, Tomoyasu Y. 2016. Functional value of elytra under various stresses in the red flour beetle. Tribolium castaneum. Scientific Reports, 6, 34813.

34. Lovei GL, Sunderland KD. 1996. Ecology and behavior of ground beetles (Coleoptera: Carabidae). Annual Review of Entomology, 41, 231-256.

35. Mortazavi A, Hajiqanbar H, Lindquist EE. 2018. A new family of mites (Acari: Prostigmata: Raphignathina), highly specialized subelytral parasites of dytiscid water beetles (Coleoptera: Dytiscidae: Dytiscinae). Zoological Journal of the Linnean Society, 184, 695-749.

36. Moser JC, Konrad H, Kirisits T, Carta LK. 2005. Phoretic mites and nematode associates of Scolytus multistriatus and Scolytus pygmaeus (Coleoptera: Scolytidae) in Austria. Agricultural and Forest Entomology, 7, 169-177.

37. Poinar GO Jr, Curcic BP, Cokendolpher JC. 1998. Arthropod phoresy involving pseudoscorpions in the past and present. Acta Arachnologica, 47, 79-96.

38. Regenfuss H. 1968. Untersuchungen zur morphologie, systematik und oekologie der Podapolipidae (Acarina: Tarsonemini). Zeitschrift für wissenschaftliche Zoologie, 177, 183-282.

39. Regenfuss H. 1972. Über die Einnischung synhospitaler Parasitenarten auf dem Wirtskörper: Untersuchungen an ektoparasitischen Milben (Podapolipidae) auf laufkäfern (Carabidae). Journal of Zoological Systematics and Evolutionary Research, 10, 44-65.

40. Schroder RF. 1982. Effect of infestation with Coccipolipus epilachnae Smiley (Acarina: Podapolipidae) on fecundity and longevity of the Mexican bean beetle. International Journal of Acarology, 8, 81-84. 
41. Seeman OD. 2019. New species of Eutarsopolipus (Trombidiformes: Podapolipidae) from the pterostichine genera Castelnaudia and Trichosternus (Coleoptera: Carabidae) in Australia. Zootaxa, 4717, 206-230.

42. Seeman OD. 2019. Two new species of Australian Eutarsopolipus (Acariformes: Podapolipidae) from Nurus medius (Coleoptera: Carabidae). Zootaxa, 4647, 134-153.

43. Seeman OD. 2020. Unusual new species of Australian Eutarsopolipus (Acariformes: Podapolipidae) from Clivina (Coleoptera: Carabidae). Annales Zoologici, 70, 425-438.

44. Seeman OD. 2021. Contrasting species diversification of Eutarsopolipus (Acariformes: Podapolipidae) on Castelnaudia and Notonomus (Coleoptera: Carabidae). Zootaxa, 4971, 1-74.

45. Seeman OD, Nahrung HF. 2013. Two new species of Chrysomelobia Regenfuss, 1968 (Acariformes: Podapolipidae) from Paropsis charybdis Stål (Coleoptera: Chrysomelidae). Systematic Parasitology, 86, 257-270.

46. Stork NE, McBroom J, Gely C, Hamilton AJ. 2015. New approaches narrow global species estimates for beetles, insects, and terrestrial arthropods. Proceedings of the National Academy of Sciences, 112, 7519-7523.

47. Trach VA, Khaustov AA. 2007. A review of mites of the family Canestriniidae (Acari, Astigmata) associated with the leaf beetles (Coleoptera, Chrysomelidae) in Ukraine with description of a new species of the genus Pseudamansia. Vestnik Zoologii, 41, 267-272.

48. van de Kamp T, Riedel A, Greven H. 2016. Micromorphology of the elytral cuticle of beetles, with an emphasis on weevils (Coleoptera: Curculionoidea). Arthropod Structure \& Development, 45, 14-22.

49. Walter DE, Lindquist EE, Smith IM, Cook DR, Krantz GW. 2009. Order Trombidiformes, in A manual of acarology, 3rd edn. Krantz GW, Walter DE, Editors. Texas Tech University Press: Texas, USA. p. 233-420.

50. Walter DE, Seeman OD. 2017. A new species of Paracarophenax (Acariformes: Acarophenacidae) with a new means of phoretic attachment. International Journal of Acarology, 43, 329-335.

51. Wohltmann A, Gabryś G, Mạkol J. 2006. Acari: Acari: Terrestrial Parasitengona inhabiting transient biotopes, in Süßwasserfauna von Mitteleuropa, Chelicerata: Araneae/Acari I. Spektrum. Gerecke R, Editor. Elsevier: München. p. 158-240.

52. Zawal A, Pešić V. 2018. The diversity of assemblages of water mites from Lake Skadar and its catchment, in The Skadar/ Shkodra Lake environment. Pešić V, Karaman GS, Kostianoy AG, Editors. Springer: Berlin.

Cite this article as: Katlav A, Hajiqanbar H, Riegler M \& Seeman OD. 2021. Sheltered life beneath elytra: three new species of Eutarsopolipus (Acari, Heterostigmatina, Podapolipidae) parasitizing Australian ground beetles. Parasite 28, 75.

\section{(0) PARASTE}

An international open-access, peer-reviewed, online journal publishing high quality papers on all aspects of human and animal parasitology

Reviews, articles and short notes may be submitted. Fields include, but are not limited to: general, medical and veterinary parasitology; morphology, including ultrastructure; parasite systematics, including entomology, acarology, helminthology and protistology, and molecular analyses; molecular biology and biochemistry; immunology of parasitic diseases; host-parasite relationships; ecology and life history of parasites; epidemiology; therapeutics; new diagnostic tools.

All papers in Parasite are published in English. Manuscripts should have a broad interest and must not have been published or submitted elsewhere. No limit is imposed on the length of manuscripts.

Parasite (open-access) continues Parasite (print and online editions, 1994-2012) and Annales de Parasitologie Humaine et Comparée (1923-1993) and is the official journal of the Société Française de Parasitologie. 